\title{
Hypoxia in deep waters of moderately eutrophic marine lakes, Island of Mljet, eastern Adriatic Sea
}

\author{
Enis Hrustić ${ }^{1}$, Svjetlana Bobanović-Ćolić ${ }^{2}$ \\ ${ }^{1}$ Ruđer Bošković Institute, Centre for Marine Research, Giordano Paliaga 5, 52210 Rovinj, Croatia. \\ (EH) (Corresponding author) E-mail: enis.hrustic@irb.hr. ORCID iD: http://orcid.org/0000-0002-5274-8649 \\ ${ }_{2}^{2}$ Institute for Marine and Coastal Research, University of Dubrovnik, Kneza Damjana Jude 12, PO box 83, \\ 20000 Dubrovnik, Croatia. \\ (SB-C) E-mail: svjetlana.bobanovic-colic@ unidu.hr. ORCID iD: http://orcid.org/0000-0003-2378-0604
}

\begin{abstract}
Summary: In this study, we explored the impact of eutrophication and stratification on hypoxia in deep waters of moderately warm Croatian marine lakes. Although the Mljet Lakes (MLs) are predominantly oligotrophic, mesotrophic conditions are present at depths below $20 \mathrm{~m}$ in the Small Lake (SL) and below $30 \mathrm{~m}$ in the Big Lake (BL), along with higher apparent oxygen utilization (AOU). Hypoxia at depths $\geq 25 \mathrm{~m}$ in SL and and $\geq 40 \mathrm{~m}$ in BL was observed between October 2009 and January 2010, and in SL in summer (July and September 2010). Significant differences $(p<0.05)$ in several physical, biological and chemical parameters were detected between the lakes, while AOU, derived oxygen utilization rate (OUR) and organic carbon remineralization rate (OCRR) were not significantly different $(p>0.05)$ between the lakes. An intense and persistent pycnocline throughout the year, comparatively high water temperature, extended water renewal time and summer phytoplankton bloom were identified as physical and biological parameters which might have significantly contributed to increased frequency of hypoxic events in a shallow SL. Significantly $(p<0.05)$ higher ammonium concentration in SL, especially in its deep water, seems to be a long-term chemical feature related to the poor ventilation and higher sediment oxygen demand. At the current level of eutrophication and the present climate change trends, the MLs and similar systems may experience more persistent and intense stratification, which could further prevent mixing between upper and deep waters, likely leading to increasing duration of hypoxia and its negative impacts on the biodiversity of benthic communities.
\end{abstract}

Keywords: hypoxia; eutrophication, marine lakes, coastal zone, Adriatic Sea, Mediterannean Sea.

Hipoxia en aguas profundas de lagos marinos moderadamente eutróficos, isla de Mljet, mar Adriático oriental

Resumen: En este estudio, exploramos el impacto de la eutrofización y la estratificación sobre la hipoxia, en aguas profundas de los lagos marinos croatas moderadamente cálidos. Aunque los lagos Mljet (LsM) son predominantemente oligotróficos, las condiciones mesotróficas están presentes a profundidades inferiores a $20 \mathrm{~m}$ en el Lago Menor (LMe) y a $30 \mathrm{~m}$ en el Lago Mayor (LMa), junto con un mayor uso del oxígeno aparente (UOA). Fue observada hipoxia a profundidades $\geq 25 \mathrm{~m}$ en el LMe $y \geq 40 \mathrm{~m}$ en el LMa entre octubre de 2009 y enero de 2010, y en LMe en verano (julio y septiembre de 2010). Fueron detectadas diferencias significativas $(\mathrm{p}<0.05)$ en varios parámetros físicos, biológicos y químicos entre los lagos, mientras que el UOA, la tasa de utilización de oxígeno derivado y la tasa de remineralización de carbono orgánico no fueron significativamente diferentes $(p>0.05)$ entre los lagos. La intensa y persistente picnoclina a lo largo del año, la temperatura comparativamente alta del agua, el tiempo prolongado de renovación del agua y la floración estival del fitoplancton se identificaron como parámetros físicos y biológicos que podrían haber contribuido significativamente incrementando la frecuencia de eventos hipóxicos en un LMe superficial. Una concentración de amonio significativamente mayor $(p<0.05)$ en LMe, especialmente en sus aguas profundas, parece ser una característica química a largo plazo relacionada con la escasa ventilación y la mayor demanda de oxígeno en los sedimentos. Al nivel actual de eutrofización con las tendencias actuales del cambio climático, los LsM y sistemas similares podrían experimentar una estratificación más persistente e intensa, lo que podría prevenir aún más la mezcla entre aguas más superficiales y profundas, conduciendo posiblemente a un incremento en la duración de la hipoxia y a los impactos negativos sobre la biodiversidad de las comunidades bentónicas.

Palabras clave: hipoxia; eutrofización; lagos marinos; zona costera; mar Adriático; mar Mediterráneo.

Citation/Como citar este artículo: Hrustić E., Bobanović-Ćolić S. 2017. Hypoxia in deep waters of moderately eutrophic marine lakes, Island of Mljet, eastern Adriatic Sea. Sci. Mar. 81(4): 431-447. doi: http://dx.doi.org/10.3989/scimar.04523.25A

Editor: X.A. Álvarez-Salgado.

Received: July 28, 2016. Accepted: September 19, 2017. Published: November 3, 2017.

Copyright: () 2017 CSIC. This is an open-access article distributed under the terms of the Creative Commons Attribution (CC-by) Spain 3.0 License. 


\section{INTRODUCTION}

Eutrophication, of either natural or anthropogenic origin, is closely connected to hypoxia in coastal seas (Nixon 1990). The cause of deficiency or absence of oxygen in aquatic systems can be of a physical origin. For example, a) sills and barriers affect circulation of water; b) excessive precipitation over evaporation intensifies the stratification that prevents mixing; and c) weak cooling of surface waters hampers water sinking and decreases water column mixing and aeration of deep waters. In addition, if a pronounced pycnocline develops in such a system, diffusion of oxygen through the density gradient can be further prevented. There are large portions of marine systems that are hypoxic, such as subsurface waters of the East China Sea (Chen et al. 2007, Wang et al. 2016) and deep waters of the Baltic Sea (Conley et al. 2009a, Rolff and Elfwing 2015), the Black Sea (Konovalov et al. 1999) and the Gulf of Mexico (Justić et al. 1996, 2005). Layers of the open ocean can be hypoxic due to a significantly larger supply of organic matter than oxygen (Kamykowski and Zentara 1990), but it is hypoxia/anoxia in coastal seas (Diaz 2001) that causes greater concern regarding damage to the biodiversity of ecosystems (Ciglenečki et al. 2015), which many human activities depend on, such as fisheries and tourism.

Lakes behave like natural laboratories because of their comparatively prompt responses to environmental changes (Ciglenečki et al. 2015). Those which contain sea water originated a few thousand years ago by processes related to late postglaciation, i.e. isostasia and elevation of sea level. The marine lakes in Scandinavia were transformed into freshwater lakes due to isostasia, and hence some of them contain the trapped sea water at the bottom (Bøyum 1973). In comparison, the marine lakes of the eastern Adriatic coast are incorporated into the system of karst, containing sea water in the entire water column (Žic et al. 2012, Hrustić et al. 2013, Ciglenečki et al. 2015). The Mljet Lakes (MLs) were formed during the Mesozoic Era as karstic depressions filled with fresh water (Govorčin et al. 2001). The postglacial sea level rose around 4 to 5 thousand years ago and consequently the ingression of sea turned them into a marine environment (Bognar and Curić 1995). Unlike the well-oxygenated Jezero Mir (Lake Mir) $\left(43.8864^{\circ} \mathrm{N} 15.1667^{\circ} \mathrm{E}\right)$, which is up to $10 \mathrm{~m}$ deep (Žic et al. 2012), and the meromictic lake Zmajevo oko (Dragon's Eye) $\left(43.5309^{\circ} \mathrm{N} 15.9588^{\circ} \mathrm{E}\right)$, which is up to $15 \mathrm{~m}$ deep, permanently hypoxic below $13 \mathrm{~m}$ and occasionally completely anoxic (Ciglenečki et al. 2015), episodes of hypoxia are expected in deep waters of the MLs (Buljan and Špan 1976) within the system of coastal karst in Croatia.

The strait (depth $\sim 0.8 \mathrm{~m}$, width $\sim 2 \mathrm{~m}$ ) between SL $\left(\sim 241000 \mathrm{~m}^{2}, \sim 3349000 \mathrm{~m}^{3}\right)$ and BL $\left(\sim 1450000 \mathrm{~m}^{2}\right.$, $\sim 58000000 \mathrm{~m}^{3}$ ) and the strait (depth $\sim 2.5 \mathrm{~m}$, width $\sim 10$ $\mathrm{m}$ ) between BL and Soline Channel (SC) (Fig. 1) hinder the exchange of deep lake waters with the adjacent coastal sea. BL is up to $49 \mathrm{~m}$ deep, with an average depth of $13.6 \mathrm{~m}$, while SL is up to $29 \mathrm{~m}$ deep, with an average depth of $7.6 \mathrm{~m}$ (Cuculić et al. 2012). The advection from the open sea occurrs strictly in the surface layer, while circulation is dominantly driven by tides $<25 \mathrm{~cm}$ and tidal phase shifts through the straits acting as filters at semidiurnal frequencies (Peharda and Vilibic 2008). The absence of upwelling, unlike from coastal waters (Batistić et al. 2013), constrains the mixing and supports the development of hypoxia in deep waters of the MLs.

Some instabilities, i.e. internal waves in deep water of BL, were explained by severe cooling and sinking of the surface water to the bottom (Buljan and Špan 1976). Such an event has not been recorded in SL so far, but some water column instability can come from lateral and bottom subaquatic karstic springs (Wunsam et al. 1999). Cuculić et al. (2012) estimated that water renewal times (WRTs) in SL and BL during the mixing period (October-March) were 81 and 70 days and during the period of stratification (April-September) they were 44 and 36 days, respectively. WRT for the stratification period refers only to the upper waters above the depth of $10 \mathrm{~m}$ in SL and $17 \mathrm{~m}$ in BL. When SL and BL were considered as one system exchanging the water with the open sea, WRTs of the MLs during the mixing and stratifed periods were 82 and 43 days, respectively. These values, being closer to WRT in SL, indicated that the exchange between BL and SL is the limiting factor for the total exchange of water in the system (Cuculić et al. 2012).

In this study, we intended to investigate the link between natural eutrophication, water column stratification and episodes of hypoxia in deep waters of moderately warm marine lakes. The arrangement of data concerning the mixing and stratification periods and water column division was adjusted to be comparable to the recent report on WRT in the MLs (Cuculić et al. 2012), while offering an extension to parts of the research that revealed an anoxic event in deep water of BL more than a decade ago (Benović et al. 2000). Anoxia in the water of the MLs was not detected after August 1996 and vertical homogenization has been noted to occur regularly since 2003 (Vilibić et al. 2010). Having apparent oxygen utilization (AOU) as an important parameter of our study, including the report on the WRT (Cuculić et al. 2012), we were able to determine oxygen utilization rate (OUR) and organic carbon remineralization rate (OCRR) (Feely et al. 2004) in the MLs for the first time, and to provide information and conclusions that may be valuable for future studies of similar environments worldwide.

\section{MATERIALS AND METHODS}

\section{Sampling}

The sampling locations and dates are presented in Table 1 and Figure 1. The stations in SL (at its deepest point), BL (Vrbovačka) and Gonoturska Bay (G) are 29, 46 and $\sim 60 \mathrm{~m}$ deep, respectively. The sampling was performed between 9 am and 3 pm, repeating the sequence SL, BL and G. 
Table 1. - Sampling dates with corresponding seasons and periods. The first three letters of each month (except for Sept.), season and period are used in the abbreviations.

\begin{tabular}{|c|c|c|c|c|c|c|c|c|c|c|c|c|}
\hline Date & $\begin{array}{c}20 \text { Oct. } \\
' 09 .\end{array}$ & $\begin{array}{c}20 \text { Nov. } \\
\text { '09. }\end{array}$ & $\begin{array}{c}18 \text { Dec. } \\
\text { '09. }\end{array}$ & $\begin{array}{l}20 \text { Jan. } \\
\text { 10. }\end{array}$ & $\begin{array}{l}15 \text { Feb. } \\
\text { ' } 10 .\end{array}$ & $\begin{array}{c}17 \text { Mar. } \\
' 10 .\end{array}$ & $\begin{array}{c}21 \text { Apr. } \\
' 10 .\end{array}$ & $\begin{array}{c}25 \text { May } \\
‘ 10 .\end{array}$ & $\begin{array}{l}24 \text { June } \\
\text { '10. }\end{array}$ & $\begin{array}{l}15 \text { July } \\
\text { ' } 10 .\end{array}$ & $\begin{array}{c}17 \text { Aug. } \\
\text { '10. }\end{array}$ & $\begin{array}{c}14 \text { Sept. } \\
' 10 .\end{array}$ \\
\hline Season & Aut & Aut & Aut & Win & Win & Win & $\mathrm{Spr}$ & $\mathrm{Spr}$ & $\mathrm{Spr}$ & Sum & Sum & Sum \\
\hline Period & Mix & Mix & Mix & Mix & Mix & Mix & Str & Str & Str & Str & Str & Str \\
\hline
\end{tabular}

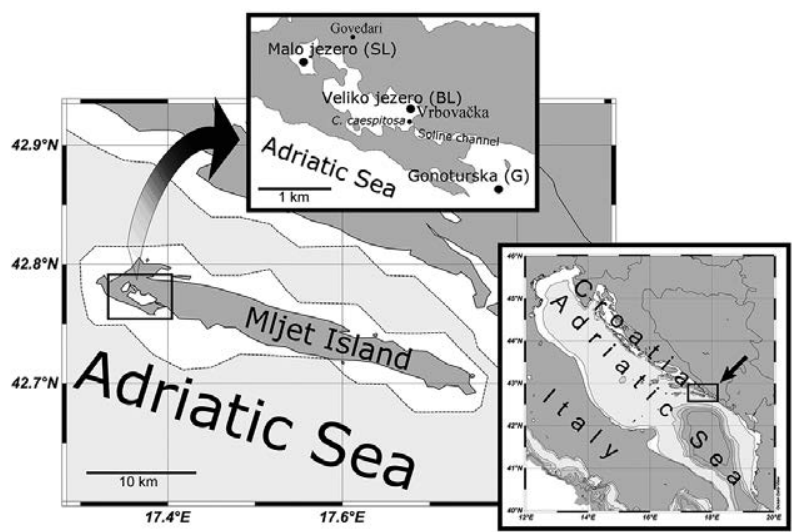

Fig. 1. - Sampling stations in the Mljet National Park: Small Lake (SL), Big Lake (BL) and Gonoturska Bay (G).

\section{Thermohaline properties, precipitation, compensa- tion depth}

Salinity (S), temperature (t) and density $\left(\sigma_{\mathrm{T}}\right)$ were determined by an SBE 19plus CTD probe at a depth resolution of $1 \mathrm{~m}$ to 27,45 and $50 \mathrm{~m}$ in SL, BL and $\mathrm{G}$ respectively. All sensors were regularly calibrated by Sea-Bird Electronics Inc. The difference in $\mathrm{t}, \mathrm{S}$ and $\sigma_{\mathrm{T}}$ for every metre of the water column depth was calculated and named $\Delta \mathrm{S}\left(\mathrm{m}^{-1}\right), \Delta \mathrm{t}\left({ }^{\circ} \mathrm{C} \mathrm{m}^{-1}\right)$ and $\Delta \sigma_{\mathrm{T}}(\mathrm{kg}$ $\mathrm{m}^{-4}$ ). The depth visibility of the white Secchi disc (Sec, diameter $30 \mathrm{~cm}$ ) was multiplied by 3 (Berman et al. $1985)$ to determine the depth of the photic zone (Pz). Data on precipitation at the nearest meteorological station to the MLs in Goveđari (Fig. 1) was ensured by Državni hidrometeorološki zavod (DHMZ, Croatian Meteorological and Hydrological Service, meteo.hr).

\section{Dissolved oxygen concentration, apparent oxygen utilization (AOU), oxygen utilization rate (OUR), organic carbon remineralization rate (OCRR) and nutrients}

The samples were collected by 5 -L Niskin bottles at the surface (0-1), 5, 10, 15, 20, 25, 30, 35, 40 and 43 $\mathrm{m}$ in BL and at the same depths up to $25 \mathrm{~m}$ in SL. The samples in $\mathrm{G}$ were taken at the same depths up to $20 \mathrm{~m}$ plus at 30, 40 and $45 \mathrm{~m}$. Dissolved $\mathrm{O}_{2}$ (DO) was precipitated in Winkler bottles and determined by iodometric titration (Grasshoff et al. 1983). The results $\left(\mathrm{ml} \mathrm{O}_{2}\right.$ $\mathrm{l}^{-1}$ ) were converted to $\mathrm{mg} \mathrm{O}_{2} \mathrm{l}^{-1}$ using the conversion factor 1.42903 (Owens and Millard 1985, Garcia and Gordon 1992, Sea-Bird Electronics Inc.). The threshold for hypoxia was set at $<2.8 \mathrm{mg} \mathrm{O}_{2} \mathrm{I}^{-1}$, as proposed by Diaz and Rosenberg (1995), which is equal to $<1.96$ $\mathrm{ml} \mathrm{O} \mathrm{l}^{-1}$ and $<87.5 \mu \mathrm{mol} \mathrm{O} \mathrm{I}^{-1}$. Anoxia stands for the environment without DO. AOU was calculated as the difference between DO concentration at saturation of $100 \%\left(\mathrm{O}_{2}{ }^{\prime}\right)$ at a given $\mathrm{S}, \mathrm{t}$ and depth (Weiss 1970) and the associated measured DO concentration, expressed as $\mu \mathrm{mol} \mathrm{O} \mathrm{kg}^{-1}$ (Feely et al. 2004). The unit for DO i.e. $\mathrm{O}_{2}\left(\mathrm{mg} \mathrm{l}^{-1}\right)$ was adjusted to the criterion for hypoxia (Diaz and Rosenberg 1995). We also calculated OUR ( $\mu \mathrm{mol} \mathrm{kg} \mathrm{kg}^{-1} \mathrm{year}^{-1}$ ) as AOU/water age (Feely et al. 2004) using corresponding individual WRTs on the basis of "e-folding time" by Cuculić et al. (2012). OCRR ( $\mu$ mol $\mathrm{kg}^{-1}$ year $^{-1}$ ) was calculated as OUR $\times \mathrm{R}_{\mathrm{C}: \mathrm{O}}$ (Feely et al. 2004), where $\mathrm{R}_{\mathrm{C}: \mathrm{O}}$ represents the molar "Redfield ratio" of C:O. We employed 0.69 for $\mathrm{R}_{\mathrm{C}: \mathrm{O}}$ as it represents an $\mathrm{R}_{\mathrm{C}: \mathrm{O}}$ of 117:170 (Anderson and Sarmiento 1994) and the average range of $\mathrm{R}_{\mathrm{C}: \mathrm{O}}(0.53-0.85)$ reported by $\mathrm{Li}$ and Peng (2002). The calculation of OCRR represents only the organic carbon mineralized when oxygen is the acceptor of the electron transport system. If another acceptor such as nitrate is also used, there will be an extra OCRR not accounted for by this calculation.

Samples $(50 \mathrm{ml})$ for analysis of ammonium $\left(\mathrm{NH}_{4}\right)$ were stabilized by addition of $2 \mathrm{ml}$ of phenol $\left(1 \mathrm{~mol} \mathrm{l}^{-1}\right)$ dissolved in 95\% vol/vol ethanol (Ivančić and Degobbis $1984)$ and stored in the dark at $4^{\circ} \mathrm{C}$. The samples (500 $\mathrm{ml}$ ) for other nutrients were stored at $-22^{\circ} \mathrm{C}$. The concentrations of nitrate $\left(\mathrm{NO}_{3}\right)$, nitrite $\left(\mathrm{NO}_{2}\right), \mathrm{NH}_{4}$, reactive silicates $\left(\mathrm{SiO}_{4}\right)$, orthophosphate $\left(\mathrm{PO}_{4}\right)$, total phosphorus (TP) and total nitrogen (TN) were determined according to Strickland and Parsons (1972) without filtration. Difference between TP and $\mathrm{PO}_{4}$ was designated as "other $\mathrm{P}$ " i.e. $\mathrm{P}_{\text {oth }}$. Difference between $\mathrm{TN}$ and dissolved inorganic nitrogen (DIN) $\left(\mathrm{NO}_{3}+\mathrm{NO}_{2}+\mathrm{NH}_{4}\right)$ was designated as "other N" i.e. $\mathrm{N}_{\text {oth }}$. The persulfate oxidation of unfiltered samples in autoclave $\left(127^{\circ} \mathrm{C}, 25 \mathrm{~min}\right)$ enabled us to measure TP (Menzel and Corwin 1965) and TN (D'Elia and Steudler 1977), which meant that $\mathrm{P}_{\text {oth }}$ and $\mathrm{N}_{\text {oth }}$ consisted of dissolved organic P (DOP) and N (DON), and non-dissolved (colloidal and particulate) organic and non-dissolved inorganic $\mathrm{P}$ and $\mathrm{N}$ species, respectively.

\section{Chlorophyll $a$ and trophic index}

DIN $\left(\mu \mathrm{g} \mathrm{l}^{-1}\right)$, TP $\left(\mu \mathrm{g} \mathrm{l}^{-1}\right)$, chlorophyll $a(\mathrm{Chl} a)(\mu \mathrm{g}$ $\left.1^{-1}\right)$ detected by the CTD probe and $\mathrm{O}_{2}$ absolute deviation $(\%)$ from saturation $\left(\mathrm{O}_{2}{ }^{\prime}\right)$ were used to calculate TRIX:

\section{$\mathrm{TRIX}=\left[\log _{10}\left(\mathrm{TP} \times \mathrm{DIN} \times \mathrm{Chl} a\left|\mathrm{O}_{2}(\%)-\mathrm{O}_{2}{ }^{\prime}(\%)\right|\right)+1.5\right] / 1.2$.}

TRIX is the trophic index first developed for the Italian northwestern Adriatic coastal waters, and it has a range of values from 0 to 10 , where $0-4,4-5,5-6$ and 6-10 indicate the high, good, moderate and poor quality of the water, respectively (Vollenweider et al. 1998). The detector of fluorescence was calibrated by the Chl $a$ measurements from the culture of a diatom 
Thalassiosira weissflogii at the Sea-Bird Electronics Inc. laboratories. The same concept was employed by Viličić et al. (2009). The data on Chl $a$ in October and November 2009 were lost, so TRIX could not be calculated for October and November 2009.

\section{Picoplankton}

The samples $(50 \mathrm{ml})$ were preserved in neutralized solution of formaldehyde ( 4\% vol/vol) on board and stored in the dark at $4^{\circ} \mathrm{C}$ until analysis. Abundance and sizes of identified picoplankton groups were determined by epifluorescent microscopy (Zeiss Jenalumar, magnification 1500). Heterotrophic bacteria ( $\mathrm{HBa})$ were detected by direct epifluorescent microscopy (Hobbie et al. 1977). Heterotrophic picoflagellates (HPF), autotrophic picoflagellates (APF) and picocyanobacteria (Cyano) were detected using proflavine (Haas 1982). Biomass of $\mathrm{HBa}$ was calculated by the conversion factor $20 \mathrm{fg} \mathrm{C} \mathrm{cell}^{-1}$ (Lee and Fuhrman 1987). Biomass of Cyano was calculated by the conversion factor $250 \mathrm{fg}$ $\mathrm{C} \operatorname{cell}^{-1}$ (Kana and Gilbert 1987). The volume $\left(\mu \mathrm{m}^{3}\right)$ of picoplankton cell categories was calculated using the equations according to morphological classes: ellipsoid $\left(\mathrm{V}=\pi \mathrm{Lw}^{2} / 6\right)$ and sphere $\left(\mathrm{V}=4 \pi \mathrm{r}^{3} / 3\right)$, where $\mathrm{L}$ is the length $(\mu \mathrm{m}), \mathrm{w}$ is the width $(\mu \mathrm{m})$ and $\mathrm{r}$ is the radius $(\mu \mathrm{m})$ of the cell. Biomass of HPF was calculated as $\mathrm{B}=\mathrm{nVFC}$, where $\mathrm{n}$ is abundance, $\mathrm{V}$ is average cell volume $\left(\mu \mathrm{m}^{3}\right)$ and $\mathrm{FC}$ is the conversion factor $0.22 \mathrm{pg}$ C $\mu \mathrm{m}^{-3}$ (Borsheim and Bratbak 1987). The equation $0.433\left(\mu \mathrm{m}^{3}\right)^{0.863}=$ pg C cell ${ }^{-1}$ (Verity et al. 1992) was employed as a conversion factor for APF by taking into account average cell volumes $\left(\mu \mathrm{m}^{3}\right)$.

\section{Statistics}

Statistica for Windows (Statsoft Inc.) was used to determine the distribution of variables by KolmogorovSmirnov and Lilliefors criteria and to calculate Spearman Rank (non-normal distribution) and Pearson's correlation coefficients ( $\mathrm{r})$ at $\mathrm{p}<0.05$ after $\log (\mathrm{x}+1)$ transformation of the data. One-way analysis of variance and Student-Newman-Keuls tests were applied to determine the significant differences $(\mathrm{p}<0.05)$ between $\mathrm{SL}, \mathrm{BL}$ and $\mathrm{G}$, representing the coastal sea. $T$ tests were employed to determine significant differences $(\mathrm{p}<0.05)$ between upper and deep waters at each location, using the depths 10 and $17 \mathrm{~m}$ (Cuculić et al. 2012) as distributors for SL and BL, respectively, while $20 \mathrm{~m}$ was employed as a distributor for G. Furthermore, $t$ tests were employed to detect significant differences $(\mathrm{p}<0.05)$ between periods of mixing (October-March) and stratification (April-September) at each location.

\section{RESULTS}

\section{The water column stratification}

We found that salinity $(\mathrm{S})$ was significantly $(\mathrm{p}<0.05)$ lower in the MLs than in G (Supplementary material Tables S1, S2). Higher surface water S in early autumn (October) (Fig. 2), also found by Miloslavić et al.
(2015), was probably related to the faster NW surface water currents (Leder et al. 1995), which introduced the open sea water into the MLs. SL was exposed to the most intense mainland influence in terms of the widest ranges of $\mathrm{t}\left(8.55-27.74^{\circ} \mathrm{C}\right)$ and $\mathrm{S}$ (31.61-38.26) (Fig. $2 \mathrm{~A})$. At SL, the coldest water $\left(8.55^{\circ} \mathrm{C}\right)$ had the lowest $\mathrm{S}$ (31.61) (depth $1 \mathrm{~m}$, December) (Fig. 2A). Also, SL had a significantly $(\mathrm{p}<0.05)$ higher $\Delta \sigma_{\mathrm{T}}$ than other locations (Table $\mathrm{S} 1, \mathrm{~S} 2$, Figs $2 \mathrm{~A}$ and $3 \mathrm{~A}) . \Delta \mathrm{S}_{\max }$ at $\mathrm{G}(0.42$ $\mathrm{m}^{-1}$ ) was detected in the 29-30 $\mathrm{m}$ layer (37.08-37.50, respectively) in January (Figs $2 \mathrm{C}$ and $3 \mathrm{C}$ ). $\Delta \mathrm{S}_{\max }$ in $\mathrm{BL}$ $\left(0.31 \mathrm{~m}^{-1}\right)$ was detected in the subsurface waters $(2-3$ $\mathrm{m}, \mathrm{S}$ 35.70-36.01, respectively) in February (Figs 2B and $3 \mathrm{~B}$ ). The situation of $\Delta \mathrm{S}$ in SL was significantly amplified: $\Delta \mathrm{S}_{\max }$ in SL $\left(2.41 \mathrm{~m}^{-1}\right)$ was detected in the subsurface water (2-3 m, S 33.17-35.58, respectively) in December, which is $\sim 6$ and 8 folds higher than the $\Delta S_{\max }$ in $\mathrm{G}$ and $\mathrm{BL}$, respectively (Figs 2 and 3). An average $\Delta \mathrm{S}$ (1-4 m, S 31.61-36.81) in SL in December equalled 1.73 $\mathrm{m}^{-1}$, almost matching the $\Delta \mathrm{S}$ in surface waters of lower parts of highly stratified estuaries on the eastern Adriatic coast (Carić et al. 2012, Cindrić et al. 2015). A sharp halocline (1-7 m) was observed in SL (December-April) (Figs $2 \mathrm{~A}$ and $3 \mathrm{~A})$. Minimum monthly $\Delta \mathrm{S}_{\max }\left(0.95 \mathrm{~m}^{-1}\right)$ in SL (6-7 m) developed in April.

The thermocline in SL appeared in March, but a deeper and more pronounced thermocline developed around the depth of $10 \mathrm{~m}$ between April and June (Figs $2 \mathrm{~A}$ and $3 \mathrm{~A})$. Further, the thermocline advanced deeper during the summer, being the strongest $\left(-2.716^{\circ} \mathrm{C} \mathrm{m}^{-1}\right)$ between 10 and $11 \mathrm{~m}\left(24.685-21.969^{\circ} \mathrm{C}\right.$, respectively) in August and the deepest in September (14-15 m, $-2.22^{\circ} \mathrm{C} \mathrm{m}^{-1}$ ). These results supported the division of the water column of SL at a depth of $10 \mathrm{~m}$, as proposed by Cuculić et al. (2012). The thermocline in BL and G developed with a small time lag after that in SL (Fig. $2)$. The most intense $\Delta \mathrm{t}$ in BL stretched from 13-16 m in April to 22-25 $\mathrm{m}$ in September (Figs 2B and 3B). $\Delta \mathrm{t}_{\max }\left(-2.107^{\circ} \mathrm{C} \mathrm{m}^{-1}\right)$ in BL developed in the $23-24 \mathrm{~m}$ layer (18.476-16.369 ${ }^{\circ} \mathrm{C}$, respectively) in September (Figs $2 \mathrm{~B}$ and $3 \mathrm{~B}$ ). $\Delta \mathrm{t}_{\max }$ did not ideally match the division of the water column in BL at a depth of $17 \mathrm{~m}$, but the most intense $\Delta \sigma_{\mathrm{T}}$ were detected in the 16-19 $\mathrm{m}$ layer, except in September (23-24 m, $\Delta \sigma_{\mathrm{T}} 0.29 \mathrm{~kg}$ $\mathrm{m}^{-4}$ ) (Figs $2 \mathrm{~B}$ and $3 \mathrm{~B}$ ), which supported the division at a depth of $17 \mathrm{~m}$, as proposed by Cuculić et al. (2012). $\Delta \mathrm{t}_{\max }$ in $\mathrm{G}\left(-0.843^{\circ} \mathrm{C} \mathrm{m}^{-1}\right)$ developed in the 3-4 m layer (21.210-20.367 ${ }^{\circ} \mathrm{C}$, respectively) in August (Figs 2C and $3 C$ ). The water column of $G$ had a notable $\Delta \sigma_{\mathrm{T}}$ in May-September, being occasionally pronounced both above and below $20 \mathrm{~m}$ (Figs $2 \mathrm{C}$ and 3C).

Deep water of $\mathrm{BL}$ was persistently colder than coastal sea at comparable depths (Fig. 2B, C). A similar finding was reported by Benović et al. (2000). The only water that is denser than the near-bottom water of $\mathrm{BL}$ in October $\left(\sigma_{\mathrm{T}} 28.81 \mathrm{~kg} \mathrm{~m}^{-3}\right.$, depth $\left.\geq 43 \mathrm{~m}\right)$ was situated below the depth of $44 \mathrm{~m}$ in $\mathrm{G}\left(\sigma_{\mathrm{T} \max } 28.83 \mathrm{~kg} \mathrm{~m}^{-3}\right.$, depth of $49 \mathrm{~m}$ ) in March (Fig. $2 \mathrm{C}) . \Delta \sigma_{\mathrm{Tmax}}$ in $\mathrm{G}\left(0.34 \mathrm{~kg} \mathrm{~m}^{-4}\right)$ was found in May (16-17 m) (Fig. 2C). $\Delta \sigma_{\mathrm{Tmax}}$ in BL (0.32 $\mathrm{kg} \mathrm{m}^{-4}, 18-19 \mathrm{~m}$, July) (Fig. 2B) was similar to that in $\mathrm{G}$, while $\Delta \sigma_{\mathrm{Tmax}}$ in SL $\left(1.44 \mathrm{~kg} \mathrm{~m}^{-4}, 2-3 \mathrm{~m}\right.$, December) exceeded the values of the highest $\Delta \sigma_{\mathrm{T}}$ in $\mathrm{BL}$ and 

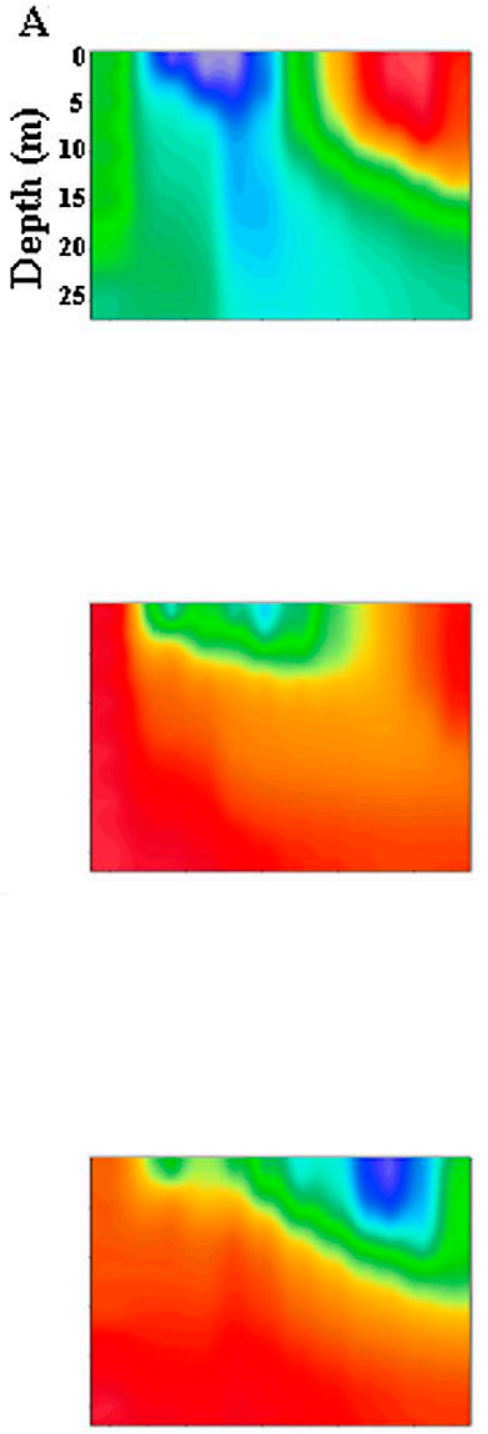

OND JFMAM J JAS
B
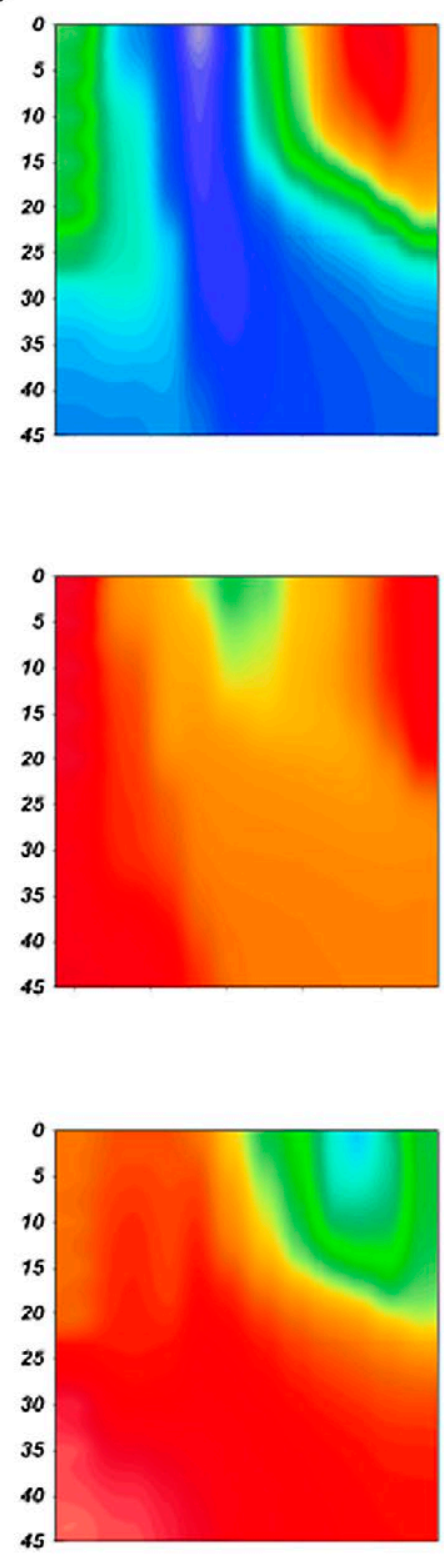

O ND JFMAM J JAS Time (October 2009-September 2010)
C Temperature $\left({ }^{\circ} \mathrm{C}\right)$
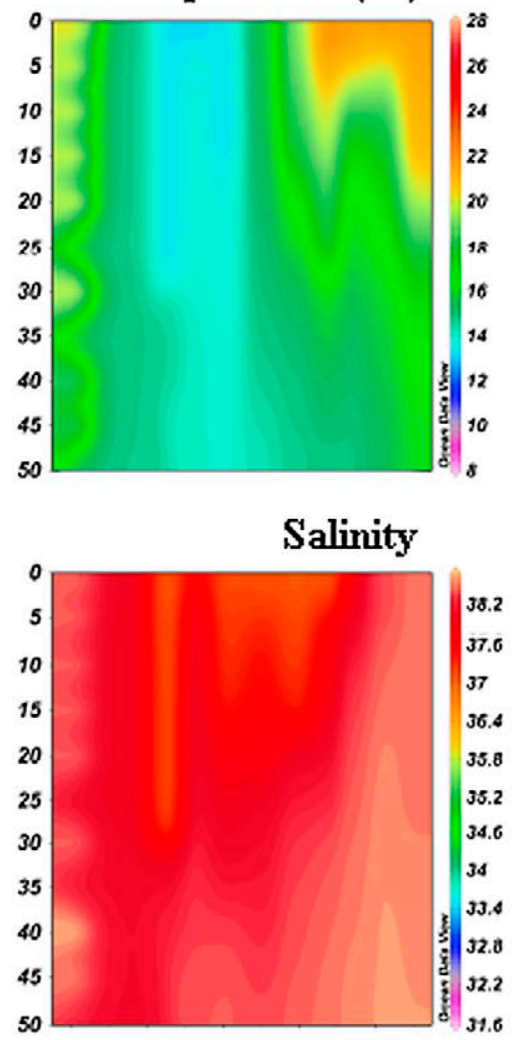

Sigma-t $\left(\mathrm{kg} \mathrm{m}^{-3}\right)$

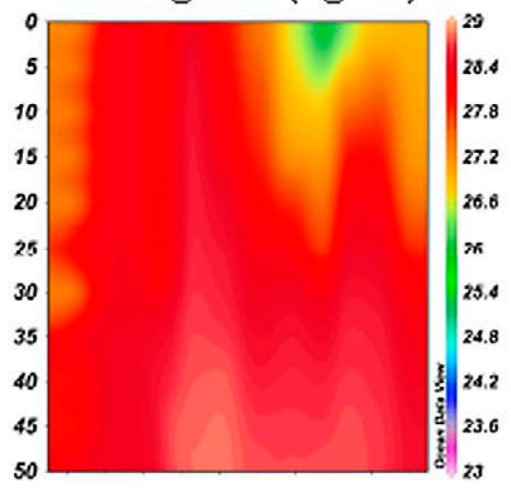

OND JFMAMJJAS

Fig. 2. - Temperature, salinity, density in Small Lake (A), Big Lake (B) and Gonoturska Bay (C).

$\mathrm{G}$ more than fourfold. In addition, all samplings in SL had greater $\Delta \sigma_{\text {Tmax }}$ (the lowest monthly $\Delta \sigma_{\text {Tmax }} 0.36 \mathrm{~kg}$ $\mathrm{m}^{-4}, 14-15 \mathrm{~m}$, September) than overall $\Delta \sigma_{\mathrm{T} \max }$ in $\mathrm{G}$ and BL. It was noted that $\Delta \sigma_{\mathrm{Tmax}}$ in SL in July was almost double $\left(0.62 \mathrm{~kg} \mathrm{~m}^{-4}, 8-9 \mathrm{~m}\right)$ the overall values, $10 \mathrm{~m}$ deeper $\Delta \sigma_{\text {Tmax }}$ in BL in July. The pycnocline in the MLs plunged deeper towards the end of summer (Fig. 2A, B).

Because of the extraordinary low $\mathrm{S}$ in the surface water of SL in December 2009, data on precipitation before and during samplings were analysed (Fig. 4). Intense precipitation from 14 to 17 December (average, $\sim 30 \mathrm{~mm} \mathrm{~m}^{-2}$ day $^{-1}$ ) significantly impacted on the lowest $\mathrm{S}$ in the surface water of SL on 18 December. By applying the partial differential equation

$$
\Delta \sigma_{\mathrm{T}}=(\partial \rho / \partial \mathrm{S})_{\mathrm{t}} \times \Delta \mathrm{S}+(\partial \rho / \partial \mathrm{t})_{\mathrm{S}} \times \Delta \mathrm{t}
$$

while keeping the $\mathrm{S}$ and $\mathrm{t}$ constant (http://www.csg network.com/h2odenscalc.html) in two separate tests between the depths of 2 and $3 \mathrm{~m}$, we concluded that $\Delta \mathrm{S}\left(2.411 \mathrm{~m}^{-1}\right)$ and $\Delta \mathrm{t}\left(2.319^{\circ} \mathrm{C} \mathrm{m}^{-1}\right)$ contributed circa $130 \%$ and $-30 \%$, respectively, to the detected $\Delta \sigma_{\mathrm{Tmax}}$ in the 2-3 m layer in SL in December.

\section{The depth of the photic zone}

Mutually different Secchi disc (Sec) values decreased from the outer station towards SL (Table 2). Minimum Sec in SL (June-July) indicated a compara- 
A
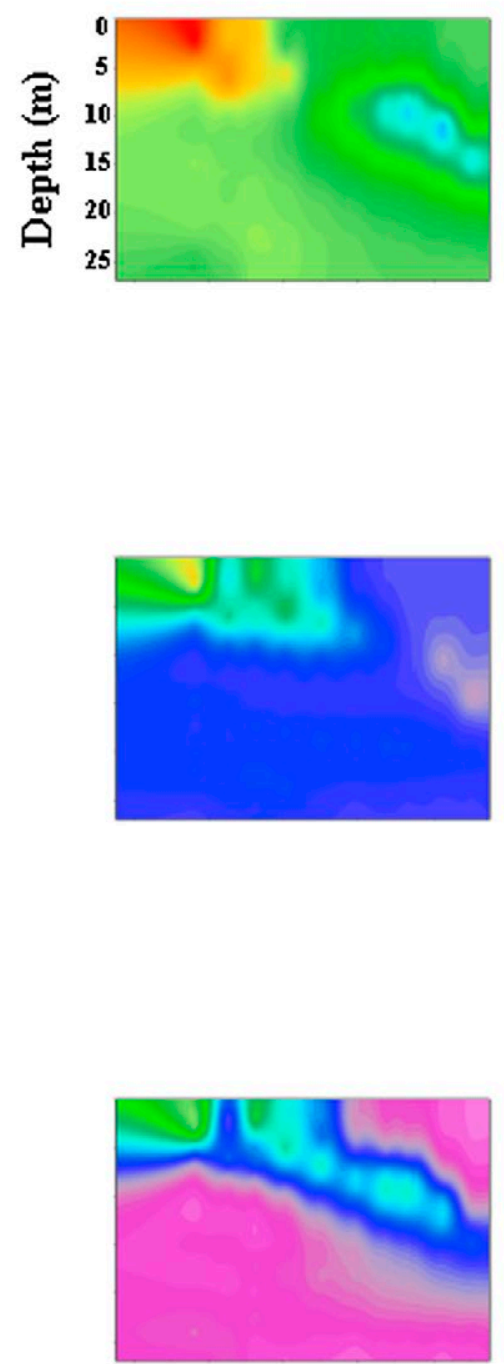

OND JFMAMJJAS
B
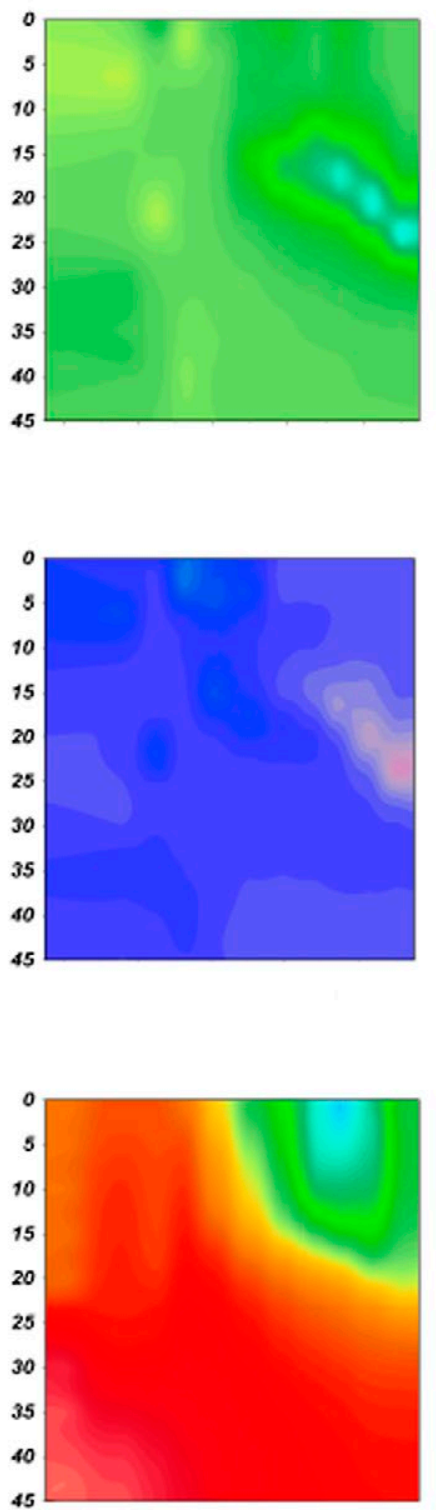

OND JFMAM J JAS Time (October 2009-September 2010)
$\mathrm{C} \quad \Delta \mathrm{t}\left({ }^{\circ} \mathrm{C} \mathrm{m}^{-1}\right)$

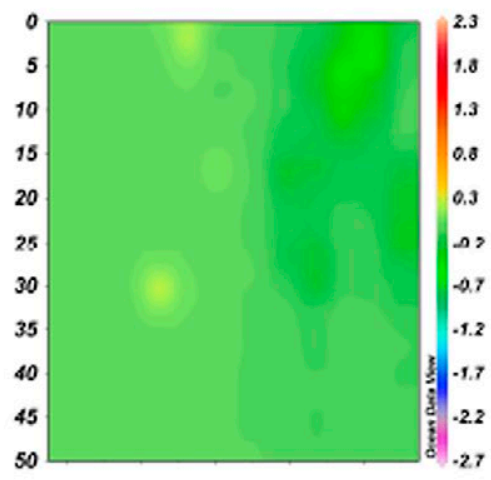

$\Delta S\left(\mathbf{m}^{-1}\right)$

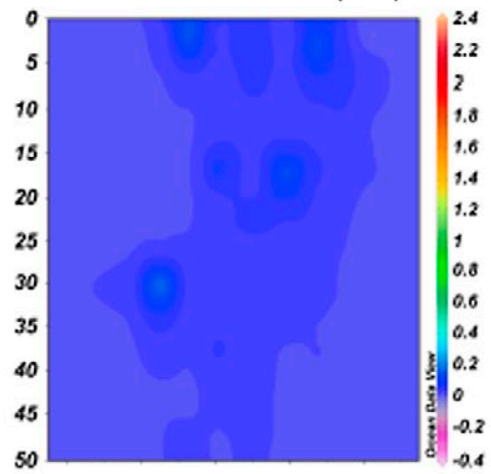

$\Delta \sigma_{\mathrm{T}}\left(\mathrm{kg} \mathrm{m} \mathbf{m}^{-4}\right)$

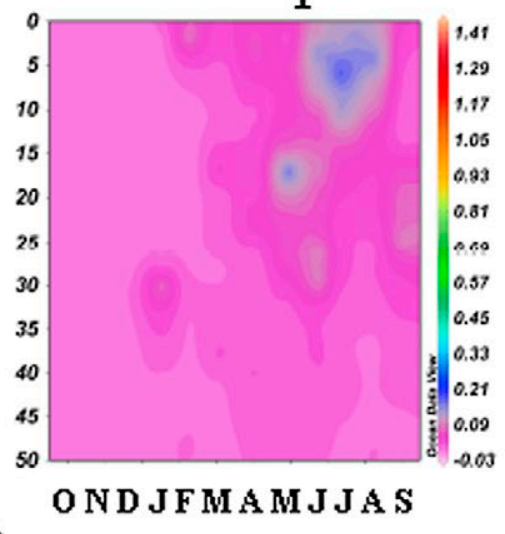

Fig. 3. - Gradients of temperature $(\Delta \mathrm{t})$, salinity $(\Delta \mathrm{S})$ and density $\left(\Delta \sigma_{\mathrm{T}}\right)$ in Small Lake (A), Big Lake (B) and Gonoturska Bay (C).

tively high concentration of suspended matter in late spring-summer, most likely due to increased biological activity. The average depth of the photic zone $(\mathrm{Pz})$ reached the bottom of the sampled water columns in $\mathrm{SL}(25 \mathrm{~m})$ and BL $(43 \mathrm{~m})$, while at $\mathrm{G}$ an average depth of the $\mathrm{Pz}(56 \mathrm{~m})$ was $11 \mathrm{~m}$ below the last sampled depth by a Niskin sampler $(45 \mathrm{~m})$. At all stations the depth of the Pz was on average 3-4 m above the surface sediments.

\section{DO, AOU, OUR and OCRR}

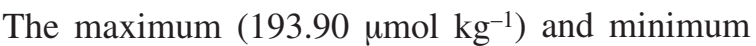
$\left(-71.89 \mu \mathrm{mol} \mathrm{kg} \mathrm{kg}^{-1}\right) \mathrm{AOU}$ were detected at $43 \mathrm{~m}$ in BL
(October) and $10 \mathrm{~m}$ in SL (August), respectively (Fig. 5A, B). There were only two samplings in SL (April, August), when $\mathrm{O}_{2}$ at $25 \mathrm{~m}$ exceeded $5 \mathrm{mg} \mathrm{l}^{-1}$ (5.16, $5.63 \mathrm{mg} \mathrm{l}^{-1}$ ) (Fig. 5A) accompanied by AOU 93.42 and $75.60 \mu \mathrm{mol} \mathrm{kg}{ }^{-1}$ (Fig. 5A), respectively. In February, March, May and June, $\mathrm{O}_{2}$ ranged from 3.13 to $4.16 \mathrm{mg}$ $\mathrm{l}^{-1}$ (Fig. 5A), with AOU from 124.00 to $155.22 \mu \mathrm{mol}$ $\mathrm{kg}^{-1}$ at $25 \mathrm{~m}$ in SL (Fig. 5A). The near-bottom waters of SL at $25 \mathrm{~m}$ were hypoxic from October to January and in July and September (Fig. 5A). In comparison, the near-bottom waters of BL (depths of 40 and $43 \mathrm{~m}$ ) were hypoxic only in the period October-January, having a range of $2.06-2.76 \mathrm{mg} \mathrm{O}_{2} \mathrm{l}^{-1}$ (Fig. 5B). In spite of having higher DO than samples from $25 \mathrm{~m}$ depth in 


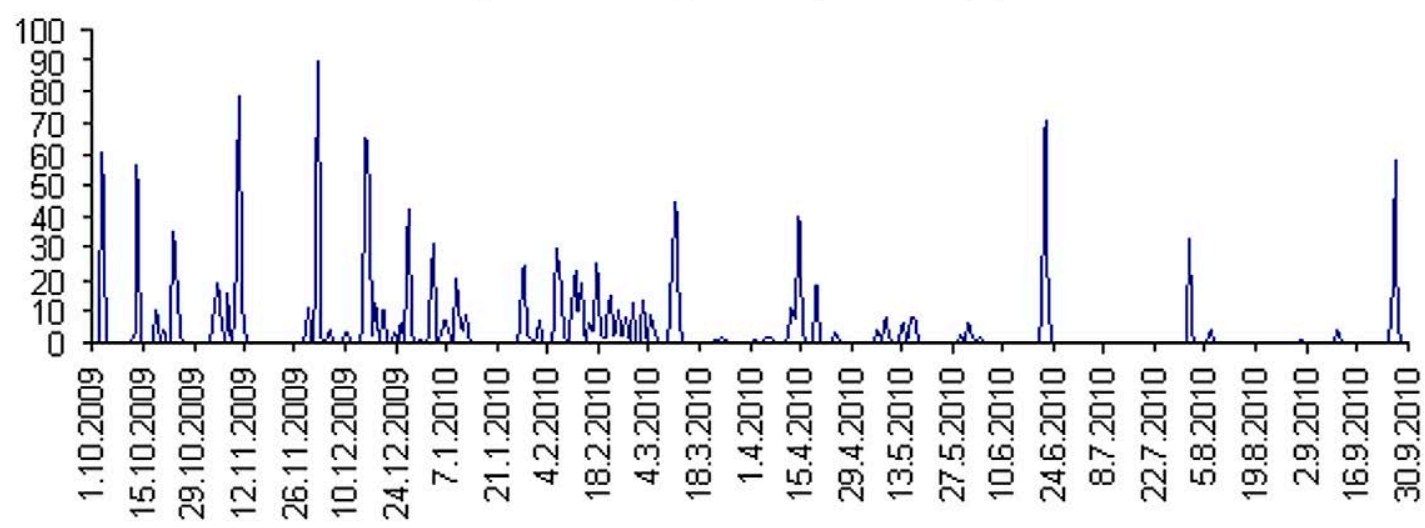

Fig. 4. - Precipitation in Goveđari, close to the Mljet Lakes (October 2009-September 2010).

Table 2. - The estimation of the photic zone depth in Small Lake (SL), Big Lake (BL) and Gonoturska Bay (G). Pz, the depth of the photic zone; Sec, the depth of the Secchi disc visibility.

\begin{tabular}{|c|c|c|c|c|}
\hline $\begin{array}{l}\text { Parameter/ } \\
\text { Location }\end{array}$ & $\begin{array}{l}\text { Sec: Min-Max (m) } \\
\text { Pz: Min-Max (m) }\end{array}$ & $\begin{array}{l}\text { Month/Year of the Min } \\
\text { Sec detection }\end{array}$ & $\begin{array}{l}\text { Month/Year of the Max } \\
\text { Sec detection }\end{array}$ & $\operatorname{Avg} \pm s d(m)$ \\
\hline SL & $\begin{array}{c}7-12 \\
\text { 21-bottom (29) }\end{array}$ & June-July ' 10. & Mar. ' 10. & $\begin{array}{l}\text { Sec: } 8.77 \pm 1.56 \\
\text { Pz: } 25.35 \pm 3.57\end{array}$ \\
\hline BL & $\begin{array}{c}11-19 \\
\text { 33-bottom (46) }\end{array}$ & June and Aug. ' 10. & Dec. '09. & $\begin{array}{l}\text { Sec: } 14.5 \pm 2.84 \\
\text { Pz: } 43.5 \pm 8.51\end{array}$ \\
\hline G & $\begin{array}{c}14.5-22 \\
43.5 \text {-bottom }(60)\end{array}$ & Jan. ' 10 & $\begin{array}{l}\text { Dec. '09 and } \\
\text { July-Aug. '10 }\end{array}$ & $\begin{array}{l}\text { Sec: } 18.77 \pm 2.69 \\
\text { Pz: } 56.25 \pm 8.49\end{array}$ \\
\hline $\begin{array}{l}t \text { tests for Sec differences } \\
\qquad(\mathrm{p}<0.01)\end{array}$ & $\begin{array}{l}\text { SL vs. BL } \\
t=4.36 \times 10^{-5}\end{array}$ & $\begin{array}{c}\text { SL vs. G } \\
t=1.78 \times 10^{-7}\end{array}$ & $\begin{array}{c}\text { BL vs. G } \\
t=3.54 \times 10^{-3}\end{array}$ & \\
\hline
\end{tabular}

SL (October-January, AOU 182.62-189.83 $\mu \mathrm{mol} \mathrm{kg}{ }^{-1}$, Fig. 5A), the deepest samples from BL (43 m) had a

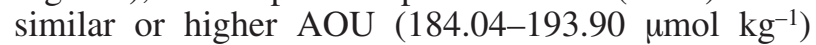
(Fig. 5B). We found that AOU in the water column of $\mathrm{G}$ was mostly negative, being negligibly positive only occasionally (three samples in December and two samples in February) (Fig. 5C), whereas AOU was positive in the whole water columns of SL and BL in December (Fig. 5A, B). Significantly greater consumption than production of $\mathrm{O}_{2}$ was detected below $20 \mathrm{~m}$ in SL and $30 \mathrm{~m}$ in $\mathrm{BL}$ throughout the whole study period (Fig. $5 \mathrm{~A}, \mathrm{~B})$. The minimum of $\mathrm{O}_{2}\left(1.70 \mathrm{mg} \mathrm{l}^{-1}\right)$ was detected at $25 \mathrm{~m}$ in SL in December (Fig. $5 \mathrm{~A}$ ), when $\Delta \sigma_{\mathrm{Tmax}}$ occurred in the subsurface water $(2-3 \mathrm{~m})$. Using individual WRTs (Cuculić et al. 2012) as the water age in SL and BL, we calculated OUR and OCRR (Table S3, S6, S9, S10).

\section{Nutrients and estimate of phytoplankton growth}

The negative correlations $(\mathrm{p}<0.05)$ between $\mathrm{O}_{2}$ and inorganic nutrients in the MLs (Table 3) were most likely associated with regeneration after decomposition of the sinking organic matter excreted by Aurelia sp. (Alvarez-Colombo et al. 2009, Tinta et al. 2016) and other zooplankton and phytoplankton. The positive correlations between $\mathrm{S}$ and $\mathrm{NO}_{3}$ in the MLs are in accordance with oxidation (i.e. remineralization) of organic matter during its sinking towards deep waters of greater S (Fig. 2A, B). SL had significantly $(\mathrm{p}<0.05)$ higher $\mathrm{NH}_{4}$ than $\mathrm{BL}$ and $\mathrm{G}$, especially in deep waters (Fig. 5A, B, C), while $\mathrm{G}$ had significantly $(\mathrm{p}<0.05)$ lower $\mathrm{SiO}_{4}$ and $\mathrm{SiO}_{4} / \mathrm{DIN}$ than the MLs (Table S1, S2). In April, $\mathrm{SiO}_{4}$ and $\mathrm{NO}_{3}$ were notably depleted in the water columns and upper waters of the MLs, respectively (Fig. 6A, B). $\mathrm{SiO}_{4}$ was significantly $(\mathrm{p}<0.05)$ correlated with $\mathrm{O}_{2}$, Chl $a$ and $\mathrm{t}$ in BL. The nutricline $\left(\mathrm{NO}_{3}\right.$ and $\left.\mathrm{SiO}_{4}\right)$ in the MLs (Fig. 6A, B), except for $\mathrm{SiO}_{4}$ in April and $\mathrm{NO}_{3}$ in $\mathrm{SL}$ in the stratification period, was accompanied by the rise of AOU under $\sim 20 \mathrm{~m}$ in $\mathrm{SL}$ and $30 \mathrm{~m}$ in $\mathrm{BL}$ (Fig. 5A, B). Concentration of $\mathrm{PO}_{4}$ had the maxima of $0.39,0.50$ and $0.71 \mu^{m o l ~}{ }^{-1}$ (not presented) in G, BL and SL at 0-1 $\mathrm{m}$ in February, at $0-1 \mathrm{~m}$ and at $5 \mathrm{~m}$ in January, respectively. Maximum $\mathrm{NO}_{2}$ concentrations of $0.28,0.24$ and $3.17 \mathrm{umol} \mathrm{l}^{-1}$ (not presented) in G, BL and SL were detected at $45 \mathrm{~m}$ in March, $30 \mathrm{~m}$ in March and $25 \mathrm{~m}$ in October, respectively. Maximum $\mathrm{NH}_{4}, \mathrm{NO}_{3}$, and $\mathrm{SiO}_{4}$ concentrations $\left(4.10,6.55\right.$ and $\left.52.50 \mu \mathrm{mol}^{-1}\right)$ were detected at $25 \mathrm{~m}$ in SL in November (Fig. 5A) and $43 \mathrm{~m}$ in BL in October and in December (Fig. 6B), respectively.

\section{Chl $a$ and TRIX}

Chl $a$ had the highest $(\mathrm{p}<0.05)$ concentration in SL (Table S1, S2). The trend of rising Chl $a$ concentration from $\mathrm{G}$ towards the more enclosed waters in SL was observed. Chl $a$ was positively correlated with depth at deeper locations (BL, G) (Table 3). Chl $a$ max (1.76 $\mu \mathrm{g}^{-1}$ ) was detected in SL at $27 \mathrm{~m}$ in March (Fig. 6A). Chl $a$ max in BL $\left(1.09 \mu \mathrm{g} \mathrm{l}^{-1}\right)$ at $40 \mathrm{~m}$ in July (Fig. 6B) might have been connected to the rich pool of nutrients (Fig. 6B) and photoadaptation of phytoplankton (Geider et al. 1997) in the colder $\left(11.78^{\circ} \mathrm{C}\right)$ deep water 
A

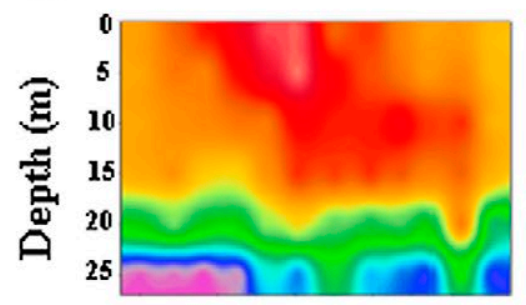

B
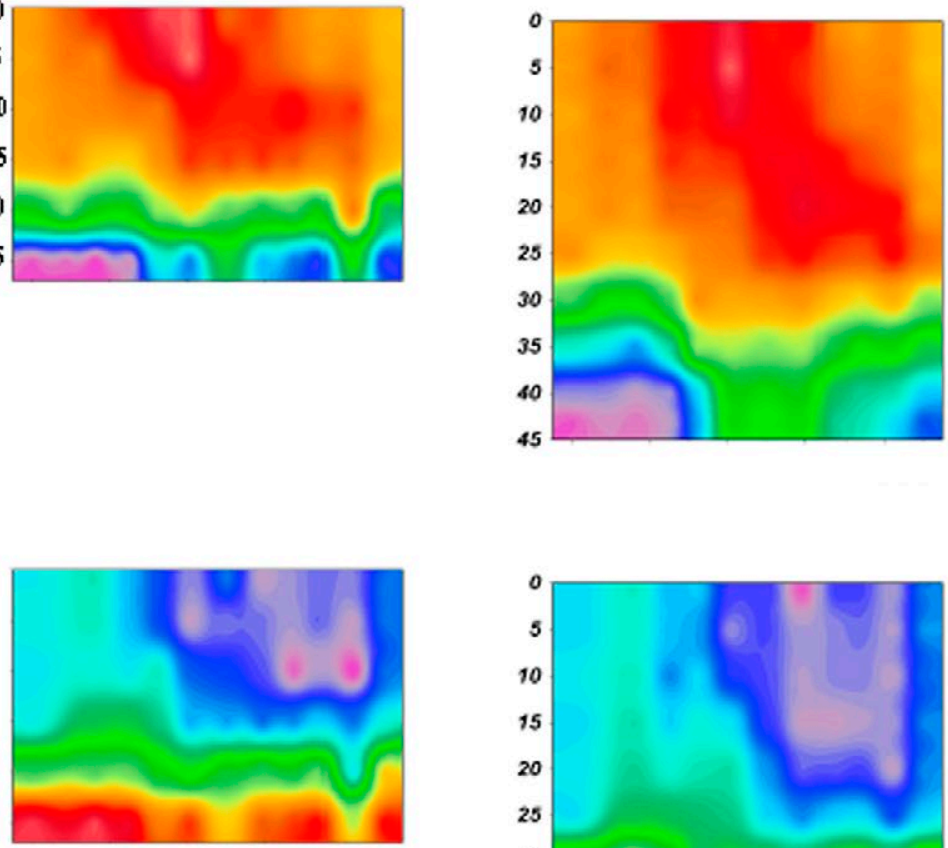

OND JFMAM J JAS

$\mathrm{C}$ $\mathrm{O}_{2}\left(\mathrm{mg} \mathrm{I}^{\mathbf{l}}\right)$

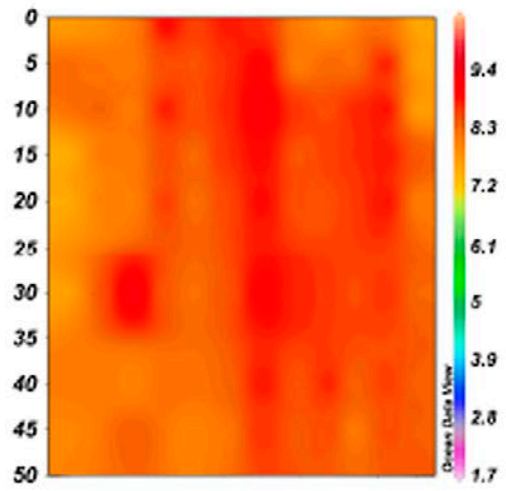

AOU (jmol kgl)
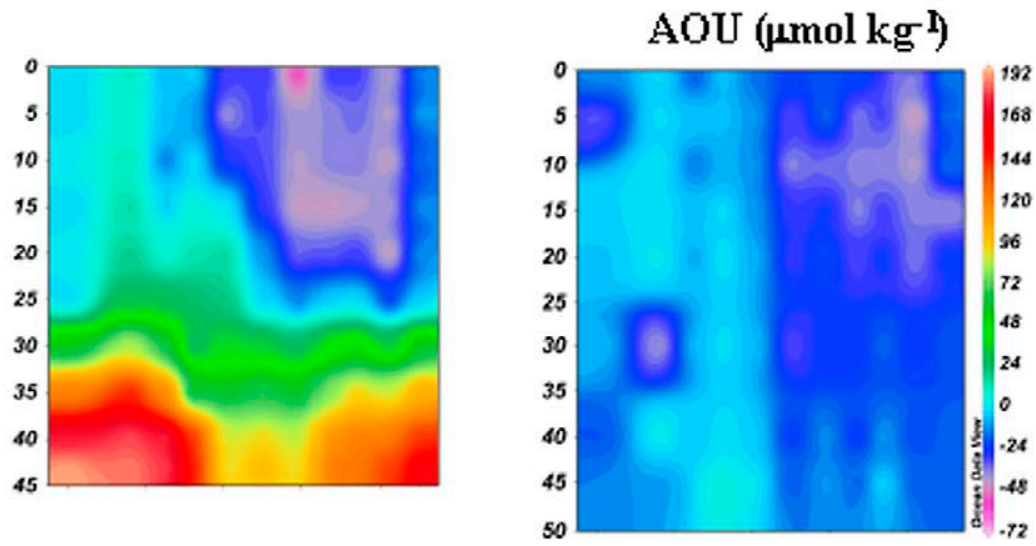

$\mathrm{NH}_{4}\left(\mu \mathrm{mol} \mathrm{r}^{\mathbf{l}}\right)$

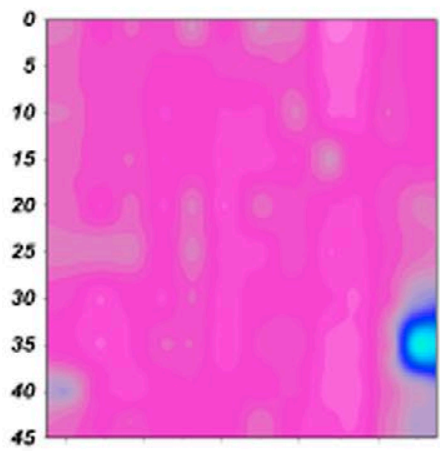

O N D J F M A M J J S Time (October 2009-September 2010)

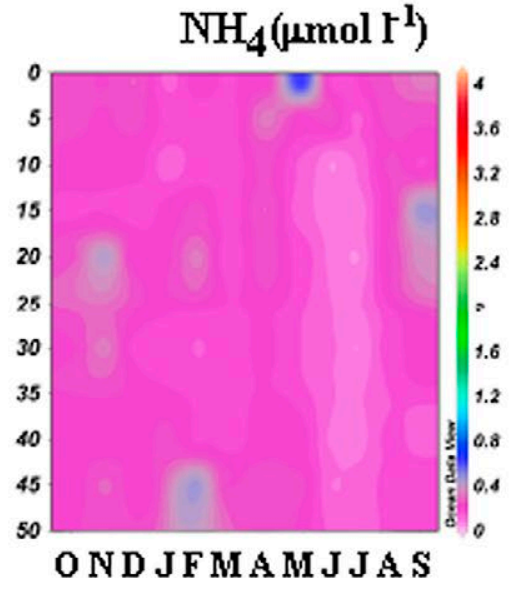

Fig. 5. - Dissolved oxygen concentration, apparent oxygen utilization and ammonium concentration in Small Lake (A), Big Lake (B) and Gonoturska Bay (C).

of BL (Fig. 2B). Seasonal development of Chl $a$ was similar for the MLs. While SL had relatively high Chl $a$ in the whole water column in April and July, BL had a notable concentration of Chl $a$ (Fig. 6A, B) only below the thermocline in the same months. Chl $a$ in BL had also positive correlations $(\mathrm{p}<0.05)$ with $\mathrm{SiO}_{4}, \mathrm{P}_{\text {oth }}, \mathrm{NO}_{3}$ and $\mathrm{NO}_{2}$ and a negative correlation $(\mathrm{p}<0.05)$ with $\mathrm{t}$. A deep chlorophyll maximum (Zavatarelli et al. 1998, Viličić et al. 2008) of $0.67 \mu \mathrm{g} \mathrm{l}^{-1}$ was detected at $49 \mathrm{~m}$ in G in July (Fig. 6C). The spring (April) and the summer (July) blooms were evident because of the higher and more homogenous $\mathrm{Chl} a$ concentrations (1.04 \pm 0.05 and $0.99 \pm 0.03 \mu \mathrm{g} \mathrm{l}^{-1}$, respectively) throughout the water column of SL. The bloom in July was accompanied by weaker hypoxia than in September, although the largest difference in $\sigma_{\mathrm{T}}$ between upper and deep waters was detected in SL in July (Fig. 2A). Hypoxia was not detected in the less eutrophicated deep water of SL in August (Figs 5A and 6A). The mesotrophic conditions (TRIX $>4$ ) dominantly developed below 20 $\mathrm{m}$ in SL and below $30 \mathrm{~m}$ in BL (Fig. 6A, B), while the investigated locations were prevailingly oligotrophic $\left(\right.$ TRIX<4). TRIX max $_{\text {max }}(4.83)$ was found at $35 \mathrm{~m}$ in BL in September (Fig. 6B). 
A

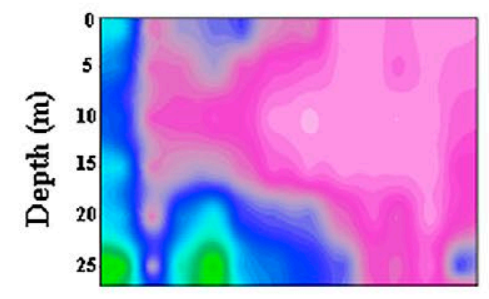

B
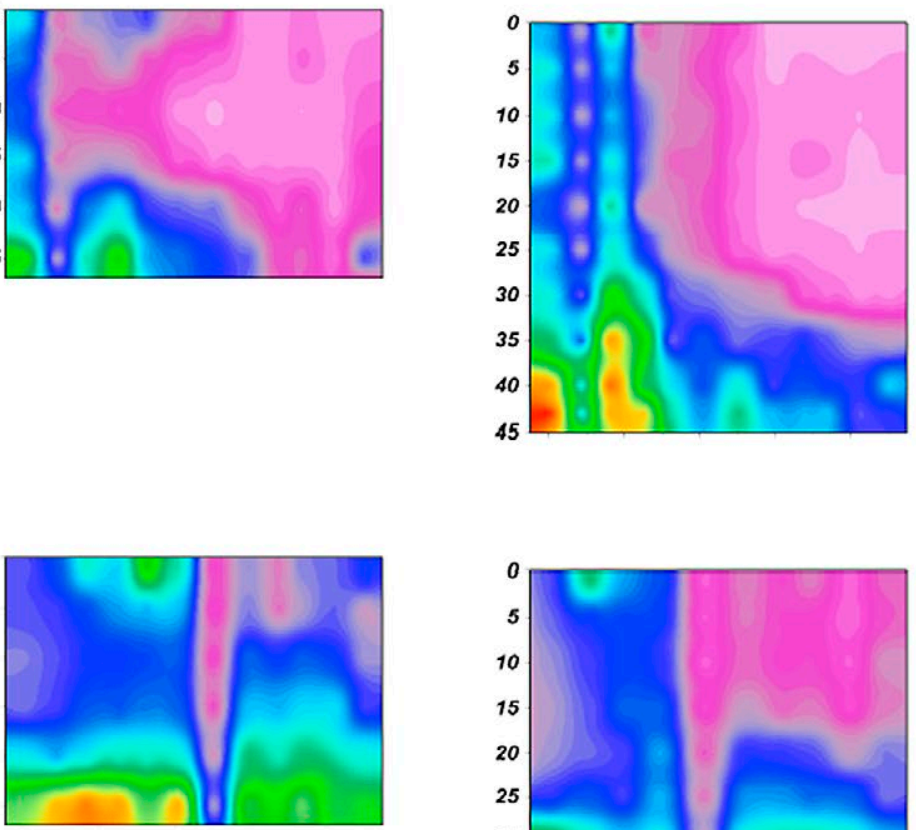

ONDJFM A M J AS


D JFMAM J J A

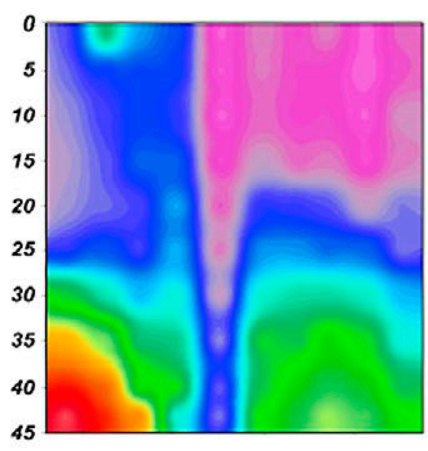

ON D JFM A M J J A S
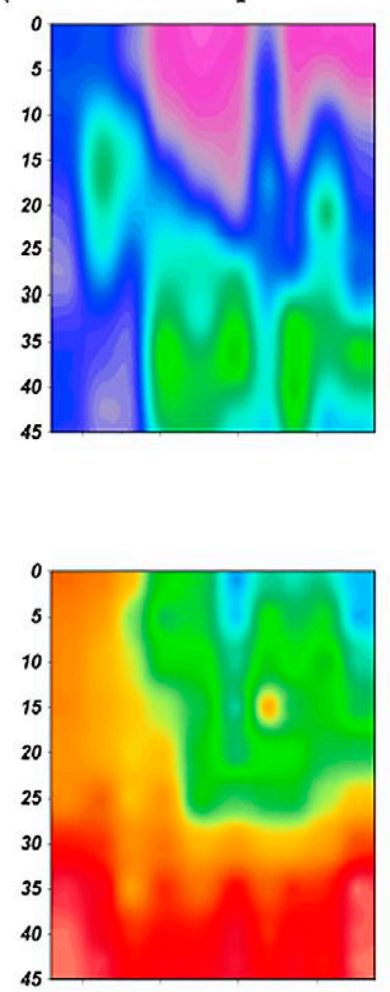

D J F M A M J A S
Time (October 2009-September 2010)

$\mathrm{C}$

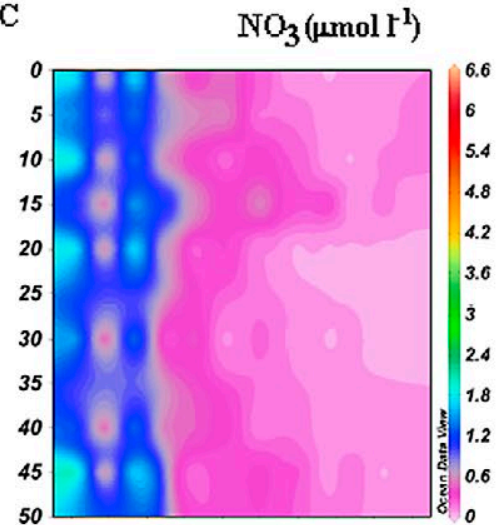

$\mathrm{SiO}_{4}\left(\mu \mathrm{mol} \mathrm{r}^{\mathbf{l}}\right)$
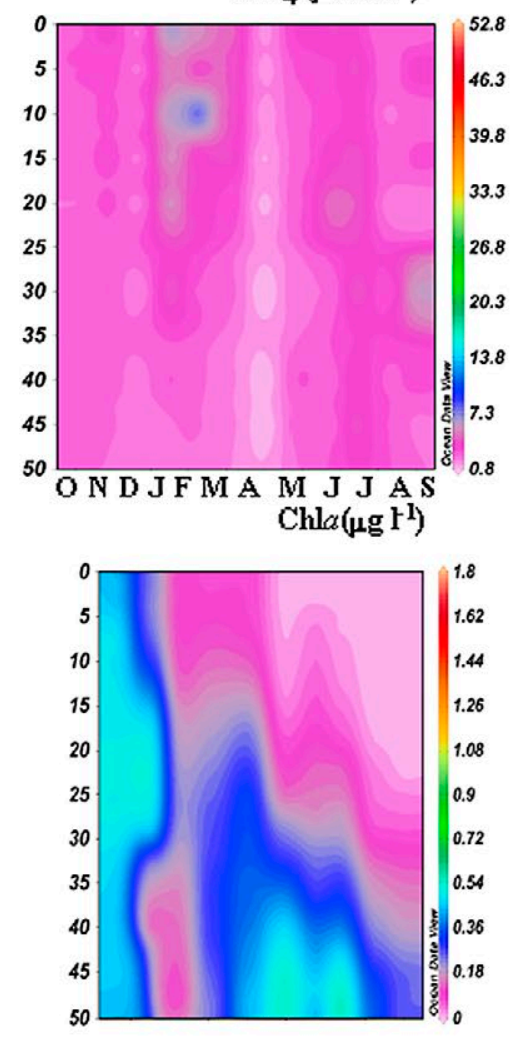

TRLX

Time (Decesther 2009-September 2010)

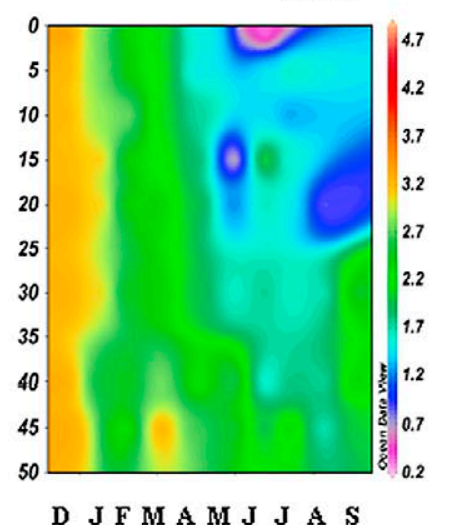

D J F M A J J A S

Fig. 6. - Nitrate concentration, silicate concentration, chlorophyll $a$ concentration and TRIX in Small Lake (A), Big Lake (B) and Gonoturska Bay (C). 
Table 3. - Significant ( $\mathrm{p}<0.05$ ) correlations (r) at explored locations in Mljet waters. SL, Small Lake; BL, Big Lake; G, Gonoturska Bay; $\mathrm{P}_{\text {oth }}$, total phosphorus concentration - $\mathrm{PO}_{4}$; t, temperature; $\mathrm{S}$, salinity; HPF, biomass of heterotrophic picoflagellates; APF, biomass of autotrophic picoflagellates; HBa, biomass of heterotrophic bacteria; Cyano, biomass of picocyanobacteria; Chl $a$, chlorophyll $a$ concentration.

\begin{tabular}{|c|c|c|c|c|c|c|c|c|c|}
\hline Location & Parameter & $\mathrm{NO}_{3}$ & $\mathrm{NO}_{2}$ & $\mathrm{NH}_{4}$ & $\mathrm{PO}_{4}$ & $\mathrm{P}_{\mathrm{oth}}$ & $\mathrm{SiO}_{4}$ & $\mathrm{t}$ & Depth \\
\hline SL & $\begin{array}{c}\mathrm{O}_{2} \\
\mathrm{~S} \\
\mathrm{t} \\
\mathrm{HPF} \\
\mathrm{APF}\end{array}$ & $\begin{array}{c}-0.45 \\
0.42 \\
-0.32\end{array}$ & & $\begin{array}{c}-0.51 \\
0.40\end{array}$ & $\begin{array}{c}-0.30 \\
0.38\end{array}$ & & & $\begin{array}{l}0.38 \\
0.47\end{array}$ & \\
\hline BL & $\begin{array}{c}\mathrm{O}_{2} \\
\mathrm{Chl} a \\
\mathrm{~S} \\
\mathrm{t} \\
\mathrm{HPF}\end{array}$ & $\begin{array}{c}-0.42 \\
0.34 \\
0.33 \\
-0.39\end{array}$ & $\begin{array}{c}-0.33 \\
0.42 \\
-0.62 \\
-0.31\end{array}$ & & -0.28 & $\begin{array}{c}-0.24 \\
0.30\end{array}$ & $\begin{array}{c}-0.39 \\
0.36 \\
-0.47\end{array}$ & $\begin{array}{c}-0.37 \\
0.48 \\
\\
0.43\end{array}$ & 0.58 \\
\hline G & $\begin{array}{c}\mathrm{O}_{2} \\
\mathrm{Chl} a \\
\mathrm{t} \\
\mathrm{HBa} \\
\text { Cyano }\end{array}$ & $\begin{array}{l}0.36 \\
0.42 \\
0.46\end{array}$ & $\begin{array}{c}0.47 \\
-0.63 \\
0.37\end{array}$ & 0.43 & 0.40 & & & $\begin{array}{c}-0.53 \\
-0.66 \\
0.37 \\
-0.41\end{array}$ & 0.59 \\
\hline
\end{tabular}

\section{Differences between the mixing and stratification period}

Although October-March was considered as the mixing period, the upper water of SL up to $7 \mathrm{~m}$ was highly stratified except in October-November because of the pronounced halocline (Fig. 2A). In the mixing period, SL had 5 and 10-fold higher $\Delta \mathrm{S}$ than $\mathrm{BL}$ and $\mathrm{G}$, respectively (Supplementary material Table S3). Unlike SL, where $\Delta S$ and $\Delta \mathrm{t}$ exchanged the leading role in defining $\Delta \sigma_{\mathrm{T}}$ during the mixing and stratification period, respectively, $\Delta \mathrm{t}$ dominantly impacted on $\Delta \sigma_{\mathrm{T}}$ in BL and G in April-September (Tables S3, S4). The mixing period for SL corresponds to the fact that, except in October and November, the upper waters of SL ( $\leq 7 \mathrm{~m})$ were notably stratified on the sampling days in the mixing period (October-March). There was no significant difference in parameters related to $\mathrm{O}_{2}$ between the mixing and stratification period in SL (Tables S3, S4, S5). AOU was significantly higher $(\mathrm{p}<0.05)$ in $\mathrm{BL}$ and $\mathrm{G}$ in the mixing period than in the stratification period (Tables S3, S4, S5).

HPF had significantly larger biomass $(\mathrm{p}<0.05)$ in SL than in G (Tables S1, S2). There was no significant difference in picoplankton between the specified periods in SL (Table S3, S4, S5). APF and HPF reacted positively to $t$ increase in SL (Table 3), but other impacts (probably grazing was the most important) did not support stronger development of the picoplankton in the warmer period (Tables S3, S4, S5). An increase in $t$ was significantly $(p<0.05)$ correlated with HPF in BL (Table 3), resulting in larger HPF in BL in the stratification period (Tables S3, S4, S5). Also, an increase in $\mathrm{t}$ resulted in significantly $(\mathrm{p}<0.05)$ higher $\mathrm{HBa}$ and lower Cyano in $\mathrm{G}$ in the stratification period. Cyano had almost unchanged averages in the MLs between the specified periods (Tables S3, S4).

Potentially limiting nutrients, according to Redfield et al. (1963), had a uniform succession: $\mathrm{PO}_{4}, \mathrm{DIN}, \mathrm{SiO}_{4}$ at all locations in the contrasting periods (Table S3, $\mathrm{S} 4)$. DIN at $\mathrm{G}$ in the stratification period was within the range $\left(0.1-0.6 \mu \mathrm{mol} \mathrm{l}^{-1}\right)$ of half saturation constant $\left(\mathrm{K}_{\mathrm{m}}\right)$ for $\mathrm{NO}_{3}$ and $\mathrm{NH}_{4}$ uptake by the phytoplankton community in the oligotrophic environment (MacIsaac and Dugdale 1969). Taking into account the compara- tively low $\mathrm{PO}_{4}$ (Table $\mathrm{S} 4$ ), it seems that phytoplankton growth at $\mathrm{G}$ during stratification was potentially $\mathrm{N}$ and $\mathrm{P}$ co-limited. $\mathrm{PO}_{4}$ concentrations at all stations were significantly $(\mathrm{p}<0.05)$ higher in the mixing period than in the stratification period (Table S5).

In the stratification period, $\mathrm{Chl} a$ was significantly $(\mathrm{p}<0.05)$ higher in SL, not significantly different in BL and significantly $(\mathrm{p}<0.05)$ lower in $\mathrm{G}$ than in the mixing period. The contrast was evident between notable Chl $a$ and $\mathrm{O}_{2}$ concentrations in the deep water of the MLs in early spring and poor Chl $a$ concentration in the same, but hypoxic water in late autumn (Figs 5A, $B$ and 6A, B). TRIX was significantly $(p<0.05)$ lower at all locations in the stratification period than in the mixing period. HPF in BL, Cyano and $\mathrm{HBa}$ in $\mathrm{G}$ had significantly different $(p<0.05)$ values between the mixing and stratification periods (Tables S3, S4, S5).

\section{Upper and deep waters in different periods}

There was no significant difference in parameters related to $\mathrm{S}$ between specified layers in each lake within the stratification period (Supplementary material Tables S6, S7, S8). All investigated locations above the thermocline had similar $\mathrm{O}_{2}$ and, according to AOU, significantly greater production than consumption of $\mathrm{O}_{2}$ (Table S6). SL had persistently higher averages of $\mathrm{O}_{2}$ sat. than BL, even at lower $\mathrm{O}_{2}$ (Table S4, S6, S7), due to significantly higher $\mathrm{t}$ than in BL (Table $\mathrm{S} 2$ ). All locations, above the thermocline, had low $\mathrm{PO}_{4}$ accompanied by $\mathrm{NO}_{3}$ and $\mathrm{NH}_{4}$ means within the range (0.1-0.6 $\left.\mu \mathrm{mol} \mathrm{1}^{-1}\right)$ of $\mathrm{K}_{\mathrm{m}}$ of their uptake by the phytoplankton community in the oligotrophic environment (MacIsaac and Dugdale 1969), indicating a potential N and P co-limitation (Table S6). The most pronounced oligotrophy was detected in $\mathrm{G}$ above the thermocline. The significant difference in $\mathrm{SiO}_{4}$ between specified layers during stratification in the MLs (Tables S6, S7, S8) might have been caused by the sinking detritus, which was notably composed of diatoms. $\mathrm{PO}_{4}$ was significantly $(\mathrm{p}<0.05)$ higher only in deep water of $\mathrm{BL}$ during the stratification period (Tables S6, S7, S8).

Chl $a$ had three and six-fold higher concentrations below the thermocline at deeper locations, BL and G, 
respectively, while $\mathrm{Chl} a$ rise in deep water of SL was not dramatic (Table S7). $\mathrm{NO}_{3}$ was three- and nine-fold higher below the thermocline in SL and BL, respectively (Table S7). All locations had low DIN above the thermocline, while G had low DIN even below the thermocline. $\mathrm{NO}_{2}$, especially in SL, and TRIX were significantly $(\mathrm{p}<0.05)$ higher below the thermocline and accompanied by higher AOU (Tables S6, S7, S8). DIN/PO 4 below the thermocline in the MLs was notably higher than Redfield's 16. Two specified layers at $\mathrm{G}$ did not show significant differences in the ratios of analysed nutrients (Table S8). APF and Cyano had significantly $(\mathrm{p}<0.05)$ higher values above the thermocline than in deep waters in SL (Tables S6, S7, S8).

Since division on mixing and stratification period did not match the reality in SL, at least for our samplings, it was preferred to determine averages and standard deviations of the study parameters in the mixing period (Tables S9, S10) associated with the same layers in the stratification period, including the test of the potentially significant $(\mathrm{p}<0.05)$ differences between the layers (Table S11) and within the same layers in different periods (Table $\mathrm{S}_{12}$ ). $\mathrm{SiO}_{4}$ in deep water of $\mathrm{G}$ was an order of magnitude lower than in the MLs (Table S10), perhaps as a consequence of the decomposition of detritus in the stagnant deep waters of the more productive MLs. The upper waters at all locations had $\mathrm{DIN} / \mathrm{PO}_{4}$ close to Redfield's 16 (Table S9), but only deep water of $\mathrm{G}$ retained similar DIN/PO $($ Table S10). Although DIN in deep waters of the MLs did not differ notably, $\mathrm{NH}_{4}$ and $\mathrm{NO}_{2}$ were more important constituents of DIN in deep water of SL, whereas $\mathrm{NO}_{3}$ was more important in deep waters of BL and G (Table S10). There were no significant changes in picoplankton constituents at all stations among upper and deep waters during the mixing period (Table S11). The largest number of significant changes between the layers occurred in SL (Table S11). This is in line with stratification of SL even in the mixing period.

\section{Same layers in different periods}

SL did not have significantly different $\Delta \sigma_{\mathrm{T}}$ between the mixing and stratification periods (Supplementary material Table S12), indicating a notable pycnocline throughout the year. Deep water of SL did not show significant differences in parameters related to $\mathrm{O}_{2}$ in different periods, while in $\mathrm{BL}$ only $\mathrm{O}_{2}$ was significantly $(\mathrm{p}<0.05)$ lower in deep water in the mixing period (Tables S7, S10, S12). The stratification period, at least in its upper waters, seemed to be more productive according to differences $(\mathrm{p}<0.05)$ in $\mathrm{O}_{2}$ sat. and parameters derived from $\mathrm{O}_{2}$ sat. (Tables S6, S9, S12). Deep waters of the MLs were moderately eutrophic in both periods (Tables S7, S10, S12). Upper water of SL did not differ significantly in $\mathrm{PO}_{4}$ between the periods (Table S12), despite an extremely high concentration of $\mathrm{PO}_{4}$ at $5 \mathrm{~m}$ in January (not presented) that lifted the average of $\mathrm{PO}_{4}$ (Table S9) notably above the average in that layer in the stratification period (Table S6). Unlike in the MLs, the Chl $a$ concentration in deep water of $\mathrm{G}$ was not significantly different between the periods (Table S12). Also, there were no significant differenc- es in parameters related to picoplankton and nutrients other than inorganic ones in water layers between the specified periods in SL (Table S12). Significant differences $(p<0.05)$ in constituents of picoplankton (HPF in $\mathrm{BL}, \mathrm{Cyano}$ and $\mathrm{HBa}$ in $\mathrm{G}$ ) and $\mathrm{N}_{\text {oth }}$ (BL and $\mathrm{G}$ ) were detected in the upper waters, while concentration of analysed organic matter differed significantly $(\mathrm{p}<0.05)$ in deep waters of BL $\left(\mathrm{N}_{\text {oth }}\right.$ and $\left.\mathrm{P}_{\text {oth }}\right)$ and $\mathrm{G}\left(\mathrm{N}_{\text {oth }}\right)$ between the specified periods (Table S12).

\section{DISCUSSION}

The lack of significant differences in any of the parameters related to $\mathrm{O}_{2}$ between the mixing and stratification periods in SL was most likely related to persistent stratification (no significant difference in $\Delta \sigma_{\mathrm{T}}$ between the mixing and stratification period), which constrained the mixing between its upper and deep water. In addition, we found the lowest numbers of parameters with significant $(\mathrm{p}<0.05)$ changes between the periods in upper and deep water of SL (Supplementary material Table S12), which are most likely related to the same reason. In comparison, the significant $(\mathrm{p}<0.05)$ differences in the upper water of $\mathrm{BL}$ (HPF) and $\mathrm{G}$ (Cyano and $\mathrm{HBa}$ ) between the periods (Table S12) are most likely a consequence of changes in the food web, which is a topic beyond the scope of this study. Of note, $\mathrm{N}_{\text {oth }}$ in $\mathrm{BL}$ and $\mathrm{G}$ was significantly $(\mathrm{p}<0.05)$ higher in the mixing period, but we cannot offer a plausible explanation for these observations.

The thermocline was crucial for stratification at all explored stations in the stratification period, while a relatively shallow (up to $7 \mathrm{~m}$ ) and persistent halocline was crucial for stratification of SL in the mixing period, to the point that difference in $\mathrm{t}$ in the 2-3 m layer in December, which impacted negatively on the pycnocline by $\sim 30 \%$, was compensated by an $130 \%$ positive influence of $\Delta S$ on $\Delta \sigma_{\mathrm{T}}$ in that layer. High range $\left(>10^{\circ} \mathrm{C}\right)$ between low and high $\mathrm{t}$ in the upper water of SL during less and more productive periods (Table S9, S6), respectively, played a role in balancing between different levels of $\mathrm{O}_{2}$ production and solubility. These include an exponentially positive relation between the rate of metabolic processes and $\mathrm{O}_{2}$ requirements of marine organisms at increasing $t$ (Brown et al. 2004), along with decreasing $\mathrm{O}_{2}$ solubility in seawater with the rise of $\mathrm{t}$ (Garcia and Gordon 1992). Ciglenečki et al. (2015) detected an increase in $\mathrm{t}$ of $1.1^{\circ} \mathrm{C}$ in the surface layer $(0-2 \mathrm{~m})$ and $0.64^{\circ} \mathrm{C}$ at $12 \mathrm{~m}$ in Dragon's Eye for 2001-2012 in comparison with 1996-2000. Therefore, we speculate that the presented trend will have greater influence on SL than on BL concerning the diminished solubility of $\mathrm{O}_{2}$ with rising t. Decreased $\mathrm{O}_{2}$ solubility in the upper water of SL in both periods due to higher $\mathrm{t}$ is mitigated by lower $\mathrm{S}$ in comparison with BL (Table S6, S9). An important difference between the MLs was the notably warmer $\left(2.12\right.$ and $\left.2^{\circ} \mathrm{C}\right)$ and somewhat saltier $(0.32$ and 0.38 ; negative effect on solubility of $\mathrm{O}_{2}$ ) deep water of SL during periods of stratification and mixing (Tables S7, S10), respectively. Although phytoplankton blooms produced organic matter and DO throughout the water column of SL in April and 
July, saltier (on average 0.198 and 0.167 ) and warmer (on average $2.242^{\circ} \mathrm{C}$ and $2.933^{\circ} \mathrm{C}$ ) deep water of SL in April and July, respectively, caused reduced solubility of $\mathrm{O}_{2}$ in comparison with deep water of BL, while having higher $\mathrm{O}_{2}$ requirements due to organisms at higher $t$ at the same time (Brown et al. 2004). It was predicted by Vaquer-Sunyer and Duarte (2011) that survival times of benthic macrofauna would decrease by a mean of $35.6 \%$ under hypoxia with the average $25.5 \%$ increase of DO concentration threshold for high mortality in a $4^{\circ} \mathrm{C}$ warmer ocean, representing the average increase in $\mathrm{t}$ expected at the end of the $21^{\text {st }}$ century under moderate $\mathrm{CO}_{2}$ emission scenarios. Along these lines, Lojen et al. (2010) have detected $4-5^{\circ} \mathrm{C}$ higher $\mathrm{t}$ $\left(12^{\circ} \mathrm{C}\right.$ in May and $13^{\circ} \mathrm{C}$ in October) in the pore water of SL than in the pore water of $\mathrm{BL}\left(8^{\circ} \mathrm{C}\right)$. Therefore, the difference of $\geq 2{ }^{\circ} \mathrm{C}$ between deep waters of SL and $\mathrm{BL}$ should be monitored in the future.

Detailed discussion on the impact of $p\left(\mathrm{CO}_{2}\right)$ and potential synergistic effects of hypoxia and increased $p\left(\mathrm{CO}_{2}\right)$ on benthic invertebrates and fish can be found in Steckbauer et al. (2015), where measurement of calcification rates are stressed as an important additional tool to provide more prediction on the future outcome of marine invertebrates. Influence of hypoxia on benthic communities of the MLs (Kružić 2002, Mikac 2003) has not been investigated. BL is a home for the scleractinian coral Cladocora caespitosa, which forms a reef (650 $\mathrm{m}^{2}$ ) between depths of 6 and $18 \mathrm{~m}$ near the Vrbovačka sampling station (Hrustić et al. 2013). While experimenting on another scleractinian coral reef, Reynaud et al. (2003) found out that calficification was decreased by $50 \%$ when $\mathrm{t}$ and $p\left(\mathrm{CO}_{2}\right)$ were both elevated, with no significant change in response to increased $p\left(\mathrm{CO}_{2}\right)$ under normal $t$. Their findings indicated a need to re-evaluate the projected decrease of marine calcification by the year 2100. Taking into account their findings, McNeil et al. (2004) reported that the annual average coral reef calcification rate will increase with future ocean warming and eventually exceed pre-industrial rates by about $35 \%$ by the year 2100 .

Although notably stratified throughout the year, anoxia did not develop in deep waters of SL. Overturn of the water column under influence of strong cooling of the surface water has not been documented in SL so far, but such events were documented in the meromictic lake Dragon's Eye a few hundred kilometres farther north, causing the mass mortality of benthic and planktonic organisms in the early autumns of 1997 (Kršinić et al. 2000, Barić et al. 2003) and 2011 (Ciglenečki et al. 2015). These events revealed that the copepod Acartia italica has been well adapted to the extreme conditions of anoxia, while some benthic Pennatae diatoms also survived anoxia in Dragon's Eye in 1997 (Barić et al. 2003). In addition, the research in the northern Adriatic Sea at $24 \mathrm{~m}$ conducted by inducing anoxia revealed that meiobenthic harpacticoid copepods from the family Cletodidae were well adapted to anoxia (Grego et al. 2014).

The absence of upwelling in the MLs indicates that diffusion is the most important mechanism of transport of dissolved matter from deep to upper waters. If up- welling were a normal feature of the $\mathrm{MLs}, \mathrm{PO}_{4}$ released from iron-bound $\mathrm{P}$ in oxygen-poor sediments would reach the upper water very fast, alleviating potential $\mathrm{P}$ limitation according to DIN: $\mathrm{PO}_{4}>16$ (Table S1) and acting as a positive feedback to increase hypoxia by stimulating phytoplankton production (Conley et al. $2009 b$ ). Deep water of SL was $>100 \%$ and $\sim 150 \%$ richer in total Fe than deep water of BL and $\mathrm{G}$ (Buljan and Špan 1976), respectively, while iron-phosphorus still remains unexplored in sediments of this system.

The experiment of fertilization of the MLs was started via addition of 21.5 tonnes of "superphosphate" in eight instalments in BL in 1954 (Buljan and Špan 1976). In total, an average of $1.15 \mu \mathrm{mol} \mathrm{PO}_{4} \mathrm{I}^{-1}$ was introduced in SC and the MLs. The system reacted by multiplying the primary productivity more than sixfold in comparison with 1953 (Buljan and Špan 1976). Hydrogen sulfide $\left(\mathrm{H}_{2} \mathrm{~S}\right)$ was almost persistently present at $25 \mathrm{~m}$ in SL between 1951 and 1956 (Buljan and Špan 1976). It was occasionally present at notable concentrations at $20 \mathrm{~m} \mathrm{(e.g.} 4.84 \mathrm{mg} \mathrm{l}^{-1}$; overall maximum $4.95 \mathrm{mg}^{-1}$ was detected in SL at $25 \mathrm{~m}$ on the same day, 11 December 1952). The fertilization experiment caused formation of $\mathrm{H}_{2} \mathrm{~S}\left(2.93 \mathrm{mg} \mathrm{l}^{-1}\right)$ at 13 $\mathrm{m}$ at Pospile Donje in BL on 20 July 1954 (Buljan and Špan 1976). These authors noted "pink and red water" at $20 \mathrm{~m}$ in SL in May and June 1953, which was most likely connected to the presence of anoxygenic phototrophic purple sulfur bacteria, commonly found at the chemocline and in the hypolimnion (Pjevac et al. 2015). Consequently, the MLs were recognized as a highly vulnerable ecosystem and became the protected area of the Mljet National Park (NP) in 1960. It has been shown that the widening and deepening of SC and its entrance to BL in 1960 mitigated anoxic conditions in the near-bottom water of SL, according to historical profiles of the redox-sensitive elements in sediment cores of the MLs (Sondi et al. 2017). WRT in the MLs before 1960 was most likely longer than the WRT estimated recently by Cuculić et al. (2012). Buljan and Špan (1976) did not detect $\mathrm{H}_{2} \mathrm{~S}$ in deep water of SL in 1961, which is in line with the statement of Sondi et al. (2017), indicating poor ventilation as one of the most important parameters linked to estimated persistent anoxia in the near-bottom water of SL before 1960.

The negative correlation $(\mathrm{p}<0.05)$ between $\mathrm{PO}_{4}$ and $\mathrm{O}_{2}$ in the water columns of the MLs is common in hypoxic waters, e.g. bottom waters of the Baltic Sea (Conley et al. 2002). The periods (Table S5) rather than water layers (Tables S8, S11), except for $\mathrm{BL}$ in the period of stratification, differed significantly $(\mathrm{p}<0.05)$ in concentration of $\mathrm{PO}_{4}$ at all stations, having higher values during the mixing period (Tables S3, S4, $\mathrm{S} 5$ ). Because of the relatively high DIN/PO $\mathrm{P}_{4}$ at high productivity in a P-enriched environment, Buljan and Span (1976) assumed $\mathrm{N}_{2}$ fixation in the MLs. A similar hypothesis, derived from the excess of $\mathrm{NO}_{3}$ in $\mathrm{SL}$ in early spring, was proposed by Hrustić et al. (2013). $\mathrm{N}_{2}$ fixation can increase eutrophication, especially if coupled with a flux of $\mathrm{PO}_{4}$ from deep water or sediments (Jensen et al. 1995) to the photic zone (Conley et al. 
2009a). In oligotrophic P-starved regions, $\mathrm{N}_{2}$ fixers can increase their competitiveness by using excessive $\mathrm{N}$ and energy to produce exoenzymes involved in utilization of DOP (Landolfi et al. 2015). The problem of eutrophication in the Baltic Sea was a good reason for the development of a new bioassay to test the distance between $\mathrm{N}$ and $\mathrm{P}$ limitation in mesotrophic surface waters (Hrustić et al. 2017). The integrated (depth of 0-10 m) samples from the ocean acidification experiment in the Tvärminne field station (Baltic Sea) in August 2012, without a bloom of diazotrophic cyanobacteria, showed the surplus of $\mathrm{P}, \mathrm{P}^{+}=0.30 \pm 0.10 \mu \mathrm{mol} \mathrm{l}^{-1}$, but the effect of ocean acidification was not detected by this method (Hrustić et al. 2017). It would be interesting to use this new bioassay in the future to explore the distance between $\mathrm{N}$ and $\mathrm{P}$ limitation in the protected mesotrophic MLs, where the food web is controlled by Aurelia sp., and the particulate feeding of Cladocora caespitosa on phytoplankton from the surface currents in BL (Hrustić et al. 2013) may supply missing nutrients in the coral reef (Wyatt et al. 2010).

Anoxia below $39 \mathrm{~m}$ in $\mathrm{BL}$ in the period 26-28 August 1996 (Benović et al. 2000) did not last for long and wintertime cooling homogenized the entire water column. Quiescent or slowly moving speciemens within a swarm of Aurelia sp. were noted just above the anoxic layer. Aurelia $s p$. were repeatedly observed in swarms with very large numbers of individuals in BL except in September 1997. The quiescent individuals above the layer of anoxia were most likely affected by hypoxia since decreasing $\mathrm{O}_{2}$ sat. from the maximum of $101 \%$ at $18.5 \mathrm{~m}$ to depleted $\mathrm{O}_{2}$ at $39 \mathrm{~m}$ (Benović et al. 2000) probably caused death to many individuals of Aurelia sp., which might have been a significant source of $\mathrm{NH}_{4}$ in BL (Tinta et al. 2010, 2016). However, deep water of SL had significantly $(\mathrm{p}<0.01)$ higher $\mathrm{NH}_{4}$ than deep water of $\mathrm{BL}$, which is, together with the gradient of $\mathrm{NH}_{4}$ concentration below the depth of $20 \mathrm{~m}$ in SL (Benović et al. 2000), in line with our results (Fig. 5A, B; Tables S7, S10).

These findings point out other reasons why $\mathrm{NH}_{4}$ in deep water of SL is significantly higher than $\mathrm{NH}_{4}$ in deep water of BL. Higher $\mathrm{t}$ and $\mathrm{Chl} a$ are positively related to phytoplankton growth (Agawin et al. 2000). Increased $\mathrm{NO}_{2}$ in the photic zone might be notably related to excretion during phytoplankton growth (Al-Qutob et al. 2002). This fits with the detection of maximum $\mathrm{NO}_{2}$ concentrations in the photic zone of $\mathrm{BL}$ and $\mathrm{G}$ in March, but is less likely to be relevant for the maximum value of $\mathrm{NO}_{2}$ in deep water of SL in October. According to the highest yearly means of $\mathrm{t}$ and $\mathrm{Chl}$ $a(\mathrm{p}<0.05)$ (Tables S1, S2), a comparatively intense phytoplankton growth was estimated for SL. However, the difference in $\mathrm{NH}_{4}$ between the MLs was markedly higher during lower production, i.e. in the mixing period when the difference in Chl $a$ was lower (Tables S3, S4). Similar findings can be seen throughout the layers in different periods, epecially in upper waters during the mixing period when $\mathrm{BL}$ had higher Chl $a$ but lower $\mathrm{NH}_{4}$ than SL (Table S9). This leads us to conclude that phytoplankton is probably not responsible for significantly higher $\mathrm{NH}_{4}$ in SL.
Because of its smaller size, SL receives more terrestrial organic and mineral detritus relative to the amount of authigenic sediment than BL (Lojen et al. 2010). Particulate organic matter (POM) undergoes remineralization through the water column. A negligible portion of POM $(\sim 1 \%)$ escapes remineralization, being passively buried in oceanic sediments (Delaney 1998), but the percentage of POM received by sediments in the shallower SL is expected to be notably higher. Sondi et al. (2017) determined oxic-anoxic boundaries in the sediment cores of SL, BL and G at depths of 2, 5 and $15 \mathrm{~cm}$, respectively, followed by the profile of dissolved iron. These results led us to conclude that surface sediments of SL have significantly higher oxygen demand than sediments of $\mathrm{BL}$ and $\mathrm{G}$, producing notably more $\mathrm{NH}_{4}$ from the increased amount of POM. That would be an explanation for the negative correlation $(\mathrm{p}<0.05)$ between $\mathrm{NH}_{4}$ and $\mathrm{O}_{2}$ in SL (Table 3). Wang et al. (2017) reported that re-aeration and sediment oxygen demand were more important than photosynthesis and water column respiration as counterbalanced coupled processes affecting the near-bottom DO concentration in the shallow estuary. Re-aeration of deep waters in the MLs is not expected in summer (Vilibić et al. 2010). Intermittent summer (July and September) hypoxia in the warmer deep water of SL can be attributed to presumably higher organic matter supply to the surface sediments, which have an increased oxygen demand. The plunge of the intense pycnocline might have contributed to hypoxia in the deep water of SL in summer.

Positive AOU in the whole water columns of SL and BL in December (not presented), as well as higher AOU at all investigated locations in autumn-winter, were most likely related to the lower photosynthetic activity. The critical depths of dominantly higher consumption than production of $\mathrm{O}_{2}$, i.e. where $\mathrm{AOU}>0$ $\mu \mathrm{mol} \mathrm{kg} \mathrm{kg}^{-1}$, involving a notable regeneration of nutrients by organic carbon remineralization, were situated $\sim 10$ m below the water columns' division points of 10 $\mathrm{m}$ for $\mathrm{SL}$ and $17 \mathrm{~m}$ for BL (Fig. 5A, B). There were no significant differences ( $\mathrm{p}>0.05)$ between MLs concerning $\mathrm{O}_{2}$, AOU, OUR and OCRR. The larger volume of water in $\mathrm{BL}$ was characterized by a net utilization of $\mathrm{O}_{2}$ (AOU $>0 \mu \mathrm{mol} \mathrm{kg} \mathrm{kg}^{-1}$ ) (Fig. $5 \mathrm{~A}, \mathrm{~B}$ ) at a higher average OUR than in SL. A larger amount of organic carbon was remineralized in deep water of BL in the mixing period, due to a higher OCRR and a larger volume of water with positive values of OCRR than in deep water of SL in the same period (results not presented, derived from AOU). This finding is in line with a presumably higher \% of POM that escapes remineralization during sinking in SL. Since we did not have data on WRT for deep waters of the MLs in the stratification period or any data on WRT in G, we performed statistical analyses for OUR and OCRR to a lesser extent.

According to the vertical profiles of $\mathrm{SiO}_{4}$ and $\mathrm{NO}_{3}$ in the MLs in April (Fig. 6A, B), we assume that diatoms were a major player in a spring bloom. It is interesting that $\mathrm{Chl} a$ had high concentrations only at depths $\geq 30 \mathrm{~m}$ in BL during the whole water column blooms in SL in April and July. Since a major player in a mesozooplankton community of BL, the calanoid 
copepod Calanus helgolandicus, cannot reproduce in SL (Miloslavić 2012), we speculate that the higher grazing on diatoms in the upper water of BL, at least in April, may explain this result. In the warmer and more oligotrophic July, when $C$. helgolandicus is expected to reside below the thermocline in $\mathrm{BL}$, it is possible that Aurelia sp. feeding on copepods had a positive effect on autotrophic biomass below the thermocline (Turk et al. 2008). In our study, maximum concentrations of nutrients (Figs 5A, B and 6A, B) in the MLs were higher than those in SL in 1997 and BL in 19971998, except for $\mathrm{PO}_{4}$ in SL and TN in BL, which were similar to the values detected in 1997-1998 (Benović et al. 2000). We could not compare TP as it was not reported by Benović et al. (2000). Average nutrient concentrations in our study seem to be similar to those reported in Benović et al. (2000) and we cannot infer more about any change in the trophic status of the study area. Under the circumstances, we could not calculate the trophic status of the MLs from the data collected two decades ago, but we present TRIX for the period October 2009-September 2010.

Steckbauer et al. (2011) proposed $3.5 \mathrm{mg} \mathrm{O}_{2} \mathrm{l}^{-1}$ as a new operational threshold to designate hypoxic waters, representing $88 \%$ of the distribution of mean lethal DO concentrations in warm coastal waters, except for those of the $12 \%$ most sensitive species. That threshold $(\sim 52 \%$ DO saturation) is less conservative than $4.6 \mathrm{mg}$ $\mathrm{O}_{2} 1^{-1}$ ( 70\% DO saturation) for warm coastal waters, representing $90 \%$ of the distribution of mean lethal DO concentrations (Vaquer-Sunyer and Duarte 2008). Therefore, it is a scientific effort of the highest priority to re-evaluate DO thresholds that define hypoxic waters, taking into account climate change trends. In this context, the MLs seem to be an excellent laboratory for studying differences in benthic communities related to a future potential $t$ increase.

Detailed research on the thermohaline properties of SL in the mixing period should be conducted to review whether the upper water tends to be markedly stratified year after year. Persistent stratification along with the present trends in climate change, e.g. higher precipitation (Justić et al. 2005), have a potential to extend the duration and impact of hypoxia. Since small systems like marine lakes respond fast to environmental changes (Ciglenečki et al. 2015, Miloslavić and Lučić 2015), research on these lakes and similar systems should be encouraged in order to gain more insights into the impacts of driving factors of hypoxia on biodiversity in moderately warm marine systems worldwide.

\section{CONCLUSIONS}

In the present study, we have demonstrated that two moderately eutrophic Mediterranean marine lakes that communicate and depend on each other, with only a few significant differences, were affected by hypoxia in different frequencies throughout the year. A long-term chemical feature of significantly higher ammonium concentration in a smaller, shallower lake more isolated from the coastal sea has been shown by comparison with data collected from the period more than a decade ago. A notable difference in temperatures of deep waters in these lakes might be one of the key parameters to focus on in future studies, for example, on the impact of driving factors of hypoxia on the benthic communities in the Mljet NP. For the first time, an apparent oxygen utilization and the OUR as well as OCRR have been presented for this study area. Although not significantly ( $>0.05)$ different between the lakes, AOU, OUR and OCRR indicated that a larger volume of deep water in BL in the mixing period was affected by net oxygen utilization and organic carbon remineralization. These findings are in line with the expectation that more POM in the shallower water escapes remineralization, and is then subsequently oxidized in the surface sediments of SL.

\section{ACKNOWLEDGEMENTS}

We thank Zoran Jurić, Božo Grmoljez, Ana Car and Marko Žarić for their help during the sampling and Rade Garić for his help in developing Figure 1. The public institution Mljet NP lent the boat for the sampling, while the Croatian Meteorological and Hydrological Service (meteo.hr) provided the data on precipitation in Goveđari, Mljet. We thank Vlado Cuculić (Ruđer Bošković Institute, Division for Marine and Environmental Research) and Mljet NP for allowing us to use the data on the water renewal time in the MLs. We would like to thank the anonymous referee for their thorough evaluation of our manuscript and insightful comments. We also thank Nan Chiang and Eliana Ruiz Martinez for their help during the preparation of the final version of the manuscript. The study was conducted within the project 275-0000000-3186 supported by the Ministry of Science, Education and Sports (Republic of Croatia).

\section{REFERENCES}

Agawin S.R.N., Duarte C.M., Agusti S. 2000. Nutrient and temperature control contribution of picoplankton to phytoplankton biomass and production. Limnol. Oceanogr. 45: 591-600. https://doi.org/10.4319/1o.2000.45.3.0591

Al-Qutob M., Häse C., Tilzer M.M., et al. 2002. Phytoplankton drives nitrite dynamics in the Gulf of Aqaba, Red Sea. Mar. Ecol. Prog. Ser. 239: 233-239. https://doi.org/10.3354/meps239233

Alvarez-Colombo G., Benović A., Malej A., et al. 2009. Acoustic survey of a jellyfish-dominated ecosystem (Mljet Island, Croatia). Hydrobiologia 616: 99-111 https://doi.org/10.1007/s10750-008-9587-6

Anderson L.A., Sarmiento J.L. 1994. Redfield ratios of remineralization determined by nutrient data analysis. Global Biogeochem. Cy. 8: 65-80. https://doi.org/10.1029/93GB03318

Barić A., Grbec B., Kušpilić G., et al. 2003. Mass mortality event in a small saline lake (Lake Rogoznica) caused by unusual holomictic conditions. Sci. Mar. 67: 129-141. https://doi.org/10.3989/scimar.2003.67n2129

Batistić M., Lučić D., Carić M., et al. 2013. Did the alien calycophoran Muggiaea atlantica outcompete its native congeneric M. kochi in the marine lakes of Mljet Island (Croatia)? Mar. Ecol. 34(Suppl. 1): 3-13. https://doi.org/10.1111/maec.1202

Benović A., Lučić D., Onofri V., et al. 2000. Ecological characteristics of the Mljet Island seawater lakes (South Adriatic Sea) with special reference to their resident populations of medusae. Sci. Mar. 64 (Suppl. 1): 197-206. https://doi.org/10.3989/scimar.2000.64s1197 
Berman T., Walline P.W., Schneller A., et al. 1985. Secchi disk record: A claim for the eastern Mediterranean. Limnol. Oceanogr. 30: 447-448.

https://doi.org/10.4319/1o.1985.30.2.0447

Bognar A., Curić L. 1995. Geomorphologic Characteristics of the Island of Mljet. In: Durbešić P., Benović A. (eds), Proceedings of the Symposium "The natural features and social valorisation of the Island Mljet": Ecological monographs 6, Croatian Ecological Society, Zagreb, pp. 73-84.

Borsheim K.Y., Bratbak G. 1987. Cell volume to cell carbon conversion factors for a bacterivorous Monas sp. enriched from seawater. Mar. Ecol. Prog. Ser. 36: 171-175. https://doi.org/10.3354/meps036171

Bøyum A. 1973. Salsvatn, a lake with old sea water. Schweiz. Z. Hydrol. 35: 262-277. https://doi.org/10.1007/BF02502922

Brown J.H., Gillooly J.F., Allen A.P., et al. 2004. Toward a metabolic theory of ecology. Ecology 85: 1771-1789. https://doi.org/10.1890/03-9000

Buljan M., Špan J. 1976. Hydrographic properties of the sea water lakes on the Island of Mljet and the adjoining sea in eastern South Adriatic Sea. Acta Adriat. 6: 1-227.

Carić M., Jasprica N., Kršinić F., et al. 2012. Hydrography, nutrients and plankton along the longitudinal section of the Ombla Estuary (south-eastern Adriatic). J. Mar. Biol. Assoc. U.K. 92: 1227-1242. https://doi.org/10.1017/S002531541100213X

Chen C.-C., Gong G.-C., Shiah F.-K. 2007. Hypoxia in the East China Sea: One of the largest coastal low-oxygen areas in the world. Mar. Env. Res. 64: 399-408. https://doi.org/10.1016/j.marenvres.2007.01.007

Ciglenečki I., Marguš M., Bura-Nakić E., et al. 2015. Impacts of extreme weather events on highly eutrophic marine ecosystem (Rogoznica Lake, Adriatic coast). Cont. Shelf. Res. 108: 144-155. https://doi.org/10.1016/j.csr.2015.05.007

Cindrić A.-M., Garnier C., Oursel B., et al. 2015. Evidencing the natural and anthropogenic processes controlling trace metals dynamic in a highly stratified estuary: The Krka River estuary (Adriatic, Croatia). Mar. Poll. Bull. 94: 199-216. https://doi.org/10.1016/j.marpolbul.2015.02.029

Conley D.J., Humborg C., Rahm L., et al. 2002. Hypoxia in the Baltic Sea and basin-scale changes in phosphorus biogeochemistry. Environ. Sci. Technol. 36: 5315-5320. https://doi.org/10.1021/es025763w

Conley D.J., Björck S., Bonsdorff E., et al. 2009a. HypoxiaRelated Processes in the Baltic Sea. Environ. Sci. Technol. 43: 3412-3420. https://doi.org/10.1021/es802762a

Conley D.J., Carstensen J., Vaquer-Sunyer R., et al. 2009b. Ecosystem thresholds with hypoxia. Hydrobiologia 629: 21-29. https://doi.org/10.1007/s10750-009-9764-2

Cuculić V., Cukrov N., Ereš Z., et al. 2012. The impact of the water masses on the spatial and temporal distribution of ecotoxicants in the Small Lake and Big Lake of the National Park Mljet. Institute Ruđer Bošković, Zagreb, Report 80 pp.

Delaney M.L. 1998. Phosphorus accumulation in marine sediments and the oceanic phosphorus cycle. Global Biogeochem. Сy. 12: 563-572. Article number 98GB02263

D'Elia C.F., Steudler P.A. 1977. Determination of total nitrogen in aqueous samples using persulfate digestion. Limnol. Oceanogr. 22: 760-764. https://doi.org/10.4319/10.1977.22.4.0760

Diaz J.R. 2001. Overview of Hypoxia around the World. J. Environ. Qual. 30: 275-281. https://doi.org/10.2134/jeq2001.302275x

Diaz J.R., Rosenberg R. 1995. Marine benthic hypoxia: a review of its ecological effects and the behavioural responses of benthic macrofauna. Oceanogr. Mar. Biol. Ann. Rev. 33: 245-303.

Feely R.A., Sabine C.L., Schlitzer R., et al. 2004. Oxygen Utilization and Organic Carbon Remineralization in the Upper Water Column of the Pacific Ocean. J. Oceanogr. 60: 45-52. https://doi.org/10.1023/B:JOCE.0000038317.01279.aa

Garcia H.E., Gordon L.I. 1992. Oxygen solubility in seawater: Better fitting equations. Limnol. Oceanogr. 37: 1307-1312. https://doi.org/10.4319/1o.1992.37.6.1307

Geider R.J., MacIntyre H.L., Kana T.M. 1997. Dynamic model of phytoplankton growth and acclimation: responses of the balanced growth rate and the chlorophyll $a$ : carbon ratio to light, nutrient-limitation and temperature. Mar. Ecol. Prog. Ser. 148:
187-200. https://doi.org/10,3354/meps 148187

Govorčin D.P., Juračić M., Horvatinčić N., et al. 2001. Holocene sedimentation in the Soline Channel (Mljet Lakes, Adriatic Sea). Nat. Croat. 10: 247-258

Grasshoff K., Ehrhardt M., Kremling K. 1983. Methods of seawater analysis - Second, Revised and extended edition. Verlag Chemie $\mathrm{GmbH}$, Weinheim, 419 pp.

Grego M., Riedel B., Stachowitsch M., et al. 2014. Meiofauna winners and losers of coastal hypoxia: case study harpacticoid copepods. Biogeosciences 11: 281-292. https://doi.org/10.5194/bg-11-281-2014

Haas L.W. 1982. Improved epifluorescence microscopy for observing planktonic micro-organisms. Ann. Inst. Oceanogr. Paris 58(Supplement S): 261-266.

Hobbie J.E., Daley R.J.S., Jasper S. 1977. Use of Nucleopore filters for counting bacteria by fluorescence microscopy. Appl. Environ. Microb. 33: 1225-1228.

Hrustić E., Carić M., Čalić M., et al. 2013. Alkaline phosphatase activity and relative importance of picophytoplankton in autumn and early spring (Mljet Lakes, eastern Adriatic Sea). Fresen. Environ. Bull. 22: 636-648.

Hrustić E., Lignell R., Riebesell U., et al. 2017. Exploring the distance between nitrogen and phosphorus limitation in mesotrophic surface waters using a sensitive bioassay. Biogeosciences 14: 379-387. https://doi.org/10.5194/bg-14-379-2017

Ivančić I., Degobbis D. 1984. An optimal manual procedure for ammonia analysis in natural waters by the indophenol blue method. Water Res. 18: 1143-1147. https://doi.org/10.1016/0043-1354(84)90230-6

Jensen H.S., Mortensen P.B., Andersen F.Ø., et al. 1995. Phosphorus cycling in a coastal marine sediment, Aarhus Bay, Denmark. Limnol. Oceanogr. 40: 908-917. https://doi.org/10.4319/10.1995.40.5.0908

Justić D., Rabalais N.N., Turner R.E. 1996. Effects of climate change on hypoxia in coastal waters: A doubled $\mathrm{CO}_{2}$ scenario for the northern Gulf of Mexico. Limnol. Oceanogr. 41: 992-1003. https://doi.org/10.4319/1o.1996.41.5.0992

Justić D., Rabalais N.N., Turner R.E. 2005. Coupling between climate variability and coastal eutrophication: Evidence and outlook for the northern Gulf of Mexico. Neth. J. Sea Res. 54: 25-35. https://doi.org/10.1016/j.seares.2005.02.008

Kamykowski D., Zentara S-J. 1990. Hypoxia in the world ocean as recorded in the historical data set. Deep-Sea Res. Part A 37: 1861-1874. https://doi.org/10.1016/0198-0149(90)90082-7

Kana T.M., Gilbert P.M. 1987. Effect of irradiance up to $2000 \mu \mathrm{E}$ $\mathrm{m}^{-1} \mathrm{~s}^{-1}$ on marine Synechococcus WH7803: I. Growth, pigmentation and cell composition. Deep-Sea Res. 34: 479-495. https://doi.org/10.1016/0198-0149(87)90001-X

Konovalov S.K., Eremeev V.N., Suvorov A.M., et al. 1999. Climatic and anthropoghenic variations in the sulfide distribution in the Black Sea. Aquat. Geochem. 5: 13-27. https://doi.org/10.1023/A:1009655502787

Kršinić F., Carić M.,Viličić D., et al. 2000. The calanoid copepod Acartia italica Steuer, phenomenon in the small saline Lake Rogoznica (Eastern Adriatic coast). J. Plankton Res. 22: 1441-1464. https://doi.org/10.1093/plankt/22.8.1441

Kružić P. 2002. Marine fauna of the Mljet National Park (Adriatic Sea, Croatia). 1. Anthozoa. Nat. Croat. 11: 265-292.

Landolfi A., Koeve W., Dietze H., et al. 2015. A new perspective on environmental controls of marine nitrogen fixation. Geophys. Res. Lett. 42: 4482-4489. https://doi.org/10.1002/2015GL063756

Leder N., Smirčić A., Gržetić Z. 1995. Seasonal changes of the sea currents in the western aquatory of the Island Mljet. In: Durbešić P., Benović A. (eds), Symposium "The natural features and social valorisation of the Island Mljet": Ecological monographs 6, Croatian Ecological Society, Zagreb, pp. 415-436.

Lee S., Fuhrman J.A. 1987. Relationships between biovolume and biomass of naturally derived marine bacterioplankton. Appl. Environ. Microb. 53: 1298-1303.

Li Y.H., Peng T.-H. 2002. Latitudinal change of remineralization ratios in the oceans and its implications for nutrient cycles. Global Biogeochem. Cy. 16: 1130. https://doi.org/10.1029/2001GB001828

Lojen S., Juračić M., Sondi I. 2010. Geochemical conditions for the 
preservation of recent aragonite-rich sediments in Mediterranean karstic marine lakes (Mljet Island, Adriatic Sea, Croatia). Mar. Freshw. Res. 61: 119-128. https://doi.org/10.1071/MF09034

MacIsaac J.J., Dugdale R.C. 1969. The kinetics of nitrate and ammonia uptake by natural populations of marine phytoplankton. Deep-Sea Res. 16: 45-57 https://doi.org/10.1016/0011-7471(69)90049-7

McNeil B.I., Matear R.J., Barnes D.J. 2004. Coral reef calcification and climate change: The effect of ocean warming. Geophys. Res. Lett. 31: L22309. https://doi.org/10.1029/2004GL021541

Menzel D.W., Corwin N. 1965. The measurement of total phosphorus in seawater based on the liberation of organically bound fractions by persulfate oxidation. Limnol. Oceanogr. 10: 280-282. https://doi.org/10.4319/1o.1965.10.2.0280

Mikac B. 2003. Echinoderrnata in the littoral area of Mljet National Park. Period. Biol. 105: 405-412.

Miloslavić M. 2012. Zooplankton dynamics in an enclosed marine ecosystem (Mljet Lakes, NP "Mljet"): seasonal and long-term changes. Ph.D. Thesis, Univ. Split, $150 \mathrm{pp}$

Miloslavić M., Lučić D. 2015. Temporal patterns of the calanoid copepod community in Veliko Jezero, an isolated marine lake (South Adriatic Sea): links to larger-scale climate changes. J. Nat. Hist. 49: 2783-2798. https://doi.org/10.1080/00222933.2015.1022618

Miloslavić M., Lučić D., Žarić M., et al. 2015. The importance of vertical habitat gradients on zooplankton distribution in an enclosed marine environment (South Adriatic Sea). Mar. Biol. Res. 11: 462-474 https://doi.org/10.1080/17451000.2014.955802

Nixon S.W. 1990. Marine eutrophication: a growing international problem. Ambio 19: 101.

Owens W.B., Millard R.C.Jr. 1985. A new algorithm for CTD oxygen calibration. J. Phys. Oceanogr. 15: 621-631. https://doi.org/10.1175/1520-0485(1985)015<0621:ANAFCO $>2.0 . \mathrm{CO} ; 2$

Peharda M., Vilibić I. 2008. Modelling the recruitment effect in a small marine protected area: the example of saltwater lakes on the Island of Mljet (Adriatic Sea). Acta Adriat. 49: 25-35.

Pjevac P., Korlević M., Berg J.S., et al. 2015. Community shift from phototrophic to chemotrophic sulfide oxidation following anoxic holomixis in a stratified seawater lake. Appl. Environ. Microbiol. 81: 298-308. https://doi.org/10.1128/AEM.02435-14

Redfield A.C., Ketchum B.H., Richards A. 1963. The influence of organisms on the composition of sea water. In: Hill M.M. (ed.), The sea: volume 2. Wiley Interscience, New York, pp. 26-77.

Reynaud S., Leclercq N., Romaine-Lioud S., et al. 2003. Interacting effects of $\mathrm{CO}_{2}$ partial pressure and temperature on photosynthesis and calcification in a scleractinian coral. Glob. Change Biol. 9: $1660-1668$ https://doi.org/10.1046/j.1365-2486.2003.00678.x

Rolff C., Elfwing T. 2015. Increasing nitrogen limitation in the Bothnian Sea, potentially caused by inflow of phosphate-rich water from the Baltic Proper. Ambio 44: 601-611. https://doi.org/10.1007/s13280-015-0675-3

Sondi I., Mikac N., Vdović N., et al. 2017. Geochemistry of recent aragonite-rich sediments in Mediterranean karstic marine lakes: Trace elements as pollution and palaeoredox proxies and indicators of authigenic mineral formation. Chemosphere 168: 786-797. https://doi.org/10.1016/j.chemosphere.2016.10.134

Steckbauer A., Duarte C.M., Carstensen J., et al. 2011. Ecosystem impacts of hypoxia: thresholds of hypoxia and pathways to recovery. Environ. Res. Lett. 6: 12 pp. Article number 025003. https://doi.org/10.1088/1748-9326/6/2/025003

Steckbauer A., Ramajo L., Hendriks I.E., et al. 2015. Synergistic effects of hypoxia and increasing $\mathrm{CO}_{2}$ on benthic invertebrates of the central Chilean coast. Front. Mar. Sci. 2: Article number 49. https://doi.org/10.3389/fmars.2015.00049

Strickland J.D.H., Parsons T.R. 1972. A Practical Handbook of Sea Water Analysis (second edition). B. Fish. Res. Board Can. 167: $1-310$

Tinta T., Malej A., Kos M., et al. 2010. Degradation of the Adriatic medusa Aurelia sp. by ambient bacteria. Hydrobiologia 645: 179-191.

https://doi.org/10.1007/s10750-010-0223-x

Tinta T., Kogovšek T., Turk V., et al. 2016. Microbial transforma- tion of jellyfish organic matter affects the nitrogen cycle in the marine water column - A Black Sea case study. J. Exp. Mar. Biol. Ecol. 475: 19-30. https://doi.org/10.1016/j.jembe.2015.10.018

Turk V., Lučić D., Flander-Putrle V., et al. 2008. Feeding of Aurelia sp. (Scyphozoa) and links to the microbial food web. Mar. Ecol. 29: 495-505.

https://doi.org/10.1111/j.1439-0485.2008.00250.x

Vaquer-Sunyer R., Duarte C.M. 2008. Thresholds of hypoxia for marine biodiversity. Proc. Natl Acad. Sci. USA. 105: $15452-15457$. https://doi.org/10.1073/pnas.0803833105

Vaquer-Sunyer R., Duarte C.M. 2011. Temperature effects on oxygen thresholds for hypoxia in marine benthic organisms. Glob. Change Biol. 17: 1788-1797. https://doi.org/10.1111/j.1365-2486.2010.02343.x

Verity P.G., Robertson C.Y., Tronzo C.R., et al. 1992. Relationships between cell volume and the carbon and nitrogen content of marine photosynthetic nanoplankton. Limnol. Oceanogr. 3: 1434-1446. https://doi.org/10.4319/1o.1992.37.7.1434

Vilibić I., Žuljević A., Nikolić V. 2010. The dynamics of a saltwater marine lake (Big Lake, Island of Mljet, Adriatic Sea) as revealed by temperature measurements. Acta Adriat. 51: 119-130.

Viličić D., Orlić M., Jasprica N. 2008. The deep chlorophyll maximum in the coastal north eastern Adriatic Sea, July 2007. Acta Bot. Croat. 67: 33-43.

Viličić D., Kuzmić M., Bosak S., et al. 2009. Distribution of phytoplankton along the thermohaline gradient in the north-eastern Adriatic channel; winter aspect. Oceanologia 51: 495-513. https://doi.org/10.5697/oc.51-4.495

Vollenweider R.A., Giovanardi F., Montanari G., et al. 1998. Characterization of the trophic conditions of marine coastal waters with special reference to the NW Adriatic Sea: proposal for a trophic scale, turbidity and generalized water quality index. Environmetrics 9: 329-357.

h t t p s : / / d o i.org/10.1002/( S I C I ) 1099 095X(199805/06)9:3<329::AID-ENV308>3.0.CO;2-9

Wang H., Dai M., Liu J., et al. 2016. Eutrophication-Driven Hypoxia in the East China Sea off the Changjiang Estuary. Environ. Sci. Technol. 50: 2255-2263. https://doi.org/10.1021/acs.est.5b0621

Wang B., Hu J., Li S., et al. 2017. A numerical analysis of biogeochemical controls with physical modulation on hypoxia during summer in the Pearl River estuary. Biogeosciences 14: 2979-2999. https://doi.org/10.5194/bg-14-2979-2017

Weiss R.F. 1970. Solubility of nitrogen, oxygen and argon in water and seawater. Deep-Sea Res. 17: 721-735. https://doi.org/10.1016/0011-7471(70)90037-9

Wunsam S., Schmidt R., Müller J. 1999. Holocene lake development of two Dalmatian lagoons (Malo and Veliko Jezero, Isle of Mljet) in respect to changes in Adriatic Sea level and climate. Palaeogeogr. Palaeoclimatol. Palaeoecol. 146: 251-281. https://doi.org/10.1016/S0031-0182(98)00147-3

Wyatt A.S.J., Lowe R.J., Humphries S., et al. 2010. Particulate nutrient fluxes over a fringing coral reef: relevant scales of phytoplankton production and mechanisms of supply. Mar. Ecol. Prog. Ser. 405: 113-130. https://doi.org/10.3354/meps08508

Zavatarelli M., Raicich F., Bregant D., et al. 1998. Climatological biogeochemical characteristics of the Adriatic Sea. J. Mar. Syst. 18: $227-263$. https://doi.org/10.1016/S0924-7963(98)00014-1

Žic V., Truesdale V.W., Garnier C., et al. 2012. The distribution of iodine in the Croatian marine lake, Mir - The missing iodate. Estuar. Coast. Shelf Sci. 115: 377-387. https://doi.org/10.1016/j.ecss.2012.07.026

\section{SUPPLEMENTARY MATERIAL}

The following supplementary material is available through the online version of this article and at the following link: http://scimar.icm.csic.es/scimar/supplm/sm04523esm.pdf

Table S1. - The yearly Avg \pm sd of the investigated parameters in Small Lake (SL), Big Lake (BL) and Gonoturska Bay (G); $\mathrm{t}$, temperature; $\Delta \mathrm{t}$, temperature change with depth; $\mathrm{S}$, salinity; $\Delta \mathrm{S}$, salinity change with depth; $\sigma_{\mathrm{T}}$, density; $\Delta \sigma_{\mathrm{T}}$, density 
change with depth; AOU, apparent oxygen utilization; Chl $a$, chlorophyll $a$; DIN, dissolved inorganic nitrogen; $\mathrm{P}_{\text {oth }}$, total phosphorus - $\mathrm{PO}_{4}, \mathrm{~N}_{\text {oth }}$, total nitrogen - DIN; TRIX, index of eutrophication (Vollenweider et al. 1998); APF, biomass of autotrophic picoflagellates; Cyano, biomass of picocyanobacteria; $\mathrm{HBa}$, biomass of heterotrophic bacteria; HPF, biomass of heterotrophic picoflagellates.

Table S2 - Significant $(\mathrm{p}<0.05)$ differences among the explored locations in Mljet waters (SL, Small Lake; BL, Big Lake; G, Gonoturska Bay). See the list of abbreviations in Table S1.

Table S3. - Mean \pm sd of the analysed parameters in the mixing period (October 2009-March 2010); n/a, not analysed; OUR, oxygen utilization rate; OCRR, organic carbon remineralization rate. See the list of abbreviations in Table S1.

Table S4. - Mean \pm sd of the analysed parameters in the stratification period (April 2010-September 2010). See the list of abbreviations in Table S1.

Table S5. - Significant $(\mathrm{p}<0.05)$ differences in the study locations between the periods of mixing (October 2009-March 2010) and stratification (April 2010-September 2010). See the list of abbreviations in Table $\mathrm{S} 1$.

Table S6. - Mean \pm sd of the analysed parameters in the upper waters of the study locations within the stratification period (April 2010-September 2010); n/a, not analysed; OUR, oxygen utilization rate; OCRR, organic carbon remineralization rate. See the list of abbreviations in Table S1.

Table S7. - Mean \pm sd of the analysed parameters in the deep waters of the study locations within the stratification period (April
2010-September 2010). See the list of abbreviations in Table S1.

Table S8 - Significant $(\mathrm{p}<0.05)$ differences at the study locations above and below the thermocline during the stratification period (April 2010-September 2010). See the list of abbreviations in Table S1.

Table S9. - Mean \pm sd of the analysed parameters in the upper waters of the study locations within the mixing period (October 2009-March 2010); n/a, not analysed; OUR, oxygen utilization rate; OCRR, organic carbon remineralization rate. See the list of abbreviations in Table S1.

Table S10. - Mean \pm sd of the analysed parameters in the deep waters of the study locations within the mixing period (October 2009-March 2010); n/a, not analysed; OUR, oxygen utilization rate; OCRR, organic carbon remineralization rate. See the list of abbreviations in Table S1.

Table S11. - Significant $(\mathrm{p}<0.05)$ differences between upper and deep waters at the study locations during the mixing period (October 2009-March 2010). OUR, oxygen utilization rate; OCRR, organic carbon remineralization rate; OUR and OCRR were not estimated for Gonoturska Bay. See the list of abbreviations in Table S1.

Table S12. - Significant $(\mathrm{p}<0.05)$ differences within the specified water layers between the periods of mixing and stratification at the study locations. OUR, oxygen utilization rate; OCRR, organic carbon remineralization rate; OUR and OCRR were not estimated for Gonoturska Bay. See the list of abbreviations in Table S1. 


\section{Hypoxia in deep waters of moderately eutrophic marine lakes, Island of Mljet, eastern Adriatic Sea}

Enis Hrustić, Svjetlana Bobanović-Ćolić

Supplementary material 
Table S1. - The yearly Avg \pm sd of the investigated parameters in Small Lake (SL), Big Lake (BL) and Gonoturska Bay (G); t, temperature; $\Delta \mathrm{t}$, temperature change with depth; S, salinity; $\Delta \mathrm{S}$, salinity change with depth; $\sigma_{\mathrm{T}}$, density; $\Delta \sigma_{\mathrm{T}}$, density change with depth; AOU, apparent oxygen utilization; Chl $a$, chlorophyll $a$; DIN, dissolved inorganic nitrogen; $\mathrm{P}_{\text {oth }}$, total phosphorus $-\mathrm{PO}_{4}, \mathrm{~N}_{\text {oth }}$, total nitrogen - DIN; TRIX, index of eutrophication (Vollenweider et al. 1998); APF, biomass of autotrophic picoflagellates; Cyano, biomass of picocyanobacteria; HBa, biomass of heterotrophic bacteria; HPF, biomass of heterotrophic picoflagellates.

\begin{tabular}{|c|c|c|c|}
\hline Parameter & Small Lake & Big Lake & Gonoturska \\
\hline $\mathrm{t}\left({ }^{\circ} \mathrm{C}\right)$ & $16.13 \pm 4.33$ & $14.39 \pm 4.38$ & $15.86 \pm 2.38$ \\
\hline$\Delta \mathrm{t}\left({ }^{\circ} \mathrm{C} \mathrm{m}^{-1}\right)$ & $-0.16 \pm 0.58$ & $-0.15 \pm 0.34$ & $-0.06 \pm 0.14$ \\
\hline $\mathrm{S}$ & $36.75 \pm 1.05$ & $36.79 \pm 0.56$ & $38.08 \pm 0.48$ \\
\hline$\Delta \mathrm{S}\left(\mathrm{m}^{-1}\right)$ & $0.11 \pm 0.27$ & $0.02 \pm 0.05$ & $0.02 \pm 0.04$ \\
\hline$\sigma_{\mathrm{T}}\left(\mathrm{kg} \mathrm{m}^{-3}\right)$ & $26.98 \pm 1.32$ & $27.40 \pm 1.04$ & $28.12 \pm 0.63$ \\
\hline$\Delta \sigma_{\mathrm{T}}\left(\mathrm{kg} \mathrm{m}^{-4}\right)$ & $0.13 \pm 0.20$ & $0.05 \pm 0.07$ & $0.03 \pm 0.04$ \\
\hline $\mathrm{O}_{2}\left(\mathrm{mg} \mathrm{l}^{-1}\right)$ & $7.16 \pm 2.19$ & $7.08 \pm 2.06$ & $8.41 \pm 0.44$ \\
\hline $\mathrm{O}_{2}$ saturation $(\%)$ & $91.82 \pm 28.91$ & $88.82 \pm 27.29$ & $108.39 \pm 6.15$ \\
\hline $\mathrm{AOU}\left(\mu \mathrm{mol} \mathrm{kg}{ }^{-1}\right)$ & $21.56 \pm 69.64$ & $30.51 \pm 68.72$ & $-19.47 \pm 13.88$ \\
\hline Chl $a\left(\mu \mathrm{g} \mathrm{l}^{-1}\right)$ & $0.53 \pm 0.33$ & $0.39 \pm 0.24$ & $0.22 \pm 0.18$ \\
\hline $\mathrm{NH}_{4}\left(\mu \mathrm{mol} \mathrm{1} 1^{-1}\right)$ & $0.49 \pm 0.61$ & $0.24 \pm 0.14$ & $0.20 \pm 0.11$ \\
\hline $\mathrm{NO}_{2}\left(\mu \mathrm{mol} \mathrm{l}^{-1}\right)$ & $0.19 \pm 0.44$ & $0.08 \pm 0.06$ & $0.07 \pm 0.07$ \\
\hline $\mathrm{NO}_{3}\left(\mu \mathrm{mol} \mathrm{l}^{-1}\right)$ & $0.62 \pm 0.78$ & $1.03 \pm 1.34$ & $0.48 \pm 0.63$ \\
\hline $\operatorname{DIN}\left(\mu \mathrm{mol} \mathrm{1}^{-1}\right)$ & $1.30 \pm 1.40$ & $1.35 \pm 1.38$ & $0.75 \pm 0.63$ \\
\hline $\mathrm{PO}_{4}\left(\mu \mathrm{mol} \mathrm{1} 1^{-1}\right)$ & $0.07 \pm 0.09$ & $0.06 \pm 0.06$ & $0.06 \pm 0.06$ \\
\hline $\mathrm{P}_{\mathrm{oth}}\left(\mu \mathrm{mol} \mathrm{l}^{-1}\right)$ & $0.09 \pm 0.09$ & $0.12 \pm 0.17$ & $0.08 \pm 0.15$ \\
\hline $\mathrm{N}_{\mathrm{oth}}\left(\mu \mathrm{mol} \mathrm{1^{-1 } )}\right.$ & $5.41 \pm 3.09$ & $5.82 \pm 4.48$ & $5.01 \pm 3.80$ \\
\hline $\mathrm{DIN} / \mathrm{PO}_{4}$ & $28.44 \pm 27.63$ & $28.39 \pm 30.42$ & $18.25 \pm 14.03$ \\
\hline $\mathrm{SiO}_{4}\left(\mu \mathrm{mol} \mathrm{l} l^{-1}\right)$ & $13.62 \pm 9.27$ & $13.96 \pm 11.92$ & $2.92 \pm 1.43$ \\
\hline $\mathrm{SiO}_{4} / \mathrm{DIN}$ & $17.72 \pm 15.20$ & $16.62 \pm 15.45$ & $7.41 \pm 7.53$ \\
\hline TRIX & $3.24 \pm 0.89$ & $3.17 \pm 0.98$ & $2.19 \pm 0.73$ \\
\hline $\mathrm{APF}\left(\mu \mathrm{g} \mathrm{C}^{-1}\right)$ & $2.98 \pm 4.69$ & $1.41 \pm 1.91$ & $1.62 \pm 2.67$ \\
\hline Cyano $\left(\mu \mathrm{g} \mathrm{C}^{-1}\right)$ & $53.40 \pm 60.66$ & $95.75 \pm 106.73$ & $80.90 \pm 82.04$ \\
\hline $\mathrm{HBa}\left(\mu \mathrm{g} \mathrm{C} 1^{-1}\right)$ & $4.12 \pm 2.21$ & $3.82 \pm 2.11$ & $3.41 \pm 0.83$ \\
\hline $\operatorname{HPF}\left(\mu \mathrm{g} \mathrm{C}^{-1}\right)$ & $2.15 \pm 2.04$ & $1.66 \pm 1.12$ & $0.99 \pm 0.76$ \\
\hline
\end{tabular}

Table S2. - Significant $(\mathrm{p}<0.05)$ differences among the explored locations in Mljet waters (SL, Small Lake; BL, Big Lake; G, Gonoturska Bay). See the list of abbreviations in Table S1.

\begin{tabular}{|c|c|c|c|}
\hline Parameter & Location & BL & SL \\
\hline $\mathrm{t}$ & $\begin{array}{c}\mathrm{G} \\
\mathrm{BL}\end{array}$ & 0.000022 & $8 \times 10^{-6}$ \\
\hline$\Delta \mathrm{t}$ & $\mathrm{G}$ & $3 \times 10^{-6}$ & $4 \times 10^{-3}$ \\
\hline S & $\mathrm{G}$ & $9 \times 10^{-6}$ & $2 \times 10^{-5}$ \\
\hline$\Delta \mathrm{S}$ & $\begin{array}{c}\mathrm{G} \\
\mathrm{BL}\end{array}$ & & $\begin{array}{l}5 \times 10^{-8} \\
4 \times 10^{-8} \\
\end{array}$ \\
\hline$\sigma_{\mathrm{T}}$ & $\begin{array}{c}\mathrm{G} \\
\mathrm{BL}\end{array}$ & $2 \times 10^{-5}$ & $\begin{array}{l}8 \times 10^{-6} \\
9 \times 10^{-6} \\
\end{array}$ \\
\hline$\Delta \sigma_{\mathrm{T}}$ & $\begin{array}{c}\mathrm{G} \\
\mathrm{BL}\end{array}$ & $7 \times 10^{-7}$ & $\begin{array}{l}1 \times 10^{-15} \\
1 \times 10^{-10}\end{array}$ \\
\hline $\mathrm{O}_{2}$ & $G$ & $4 \times 10^{-4}$ & $6 \times 10^{-4}$ \\
\hline $\mathrm{AOU}$ & $\mathrm{G}$ & $2 \times 10^{-11}$ & $1 \times 10^{-5}$ \\
\hline Chl $a$ & $\begin{array}{c}\mathrm{G} \\
\mathrm{BL}\end{array}$ & $2 \times 10^{-5}$ & $\begin{array}{l}8 \times 10^{-6} \\
9 \times 10^{-6}\end{array}$ \\
\hline $\mathrm{NH}_{4}$ & $\begin{array}{c}\mathrm{G} \\
\mathrm{BL}\end{array}$ & & $\begin{array}{l}3 \times 10^{-5} \\
8 \times 10^{-4}\end{array}$ \\
\hline $\mathrm{NO}_{2}$ & $\begin{array}{c}\mathrm{G} \\
\mathrm{BL}\end{array}$ & & $\begin{array}{l}2 \times 10^{-2} \\
2 \times 10^{-2} \\
\end{array}$ \\
\hline $\mathrm{SiO}_{4}$ & $\mathrm{G}$ & $2 \times 10^{-5}$ & $8 \times 10^{-6}$ \\
\hline $\mathrm{SiO}_{4} / \mathrm{DIN}$ & $\mathrm{G}$ & $3 \times 10^{-4}$ & $2 \times 10^{-5}$ \\
\hline TRIX & $\mathrm{G}$ & $8 \times 10^{-6}$ & $2 \times 10^{-5}$ \\
\hline HPF & $\mathrm{G}$ & & $6 \times 10^{-3}$ \\
\hline
\end{tabular}


Table S3. - Mean \pm sd of the analysed parameters in the mixing period (October 2009-March 2010); n/a, not analysed; OUR, oxygen utilization rate; OCRR, organic carbon remineralization rate. See the list of abbreviations in Table S1.

\begin{tabular}{|c|c|c|c|}
\hline Parameter/Location & Small Lake & Big Lake & Gonoturska \\
\hline $\mathrm{t}\left({ }^{\circ} \mathrm{C}\right)$ & $13.60 \pm 1.84$ & $12.23 \pm 1.64$ & $14.21 \pm 1.37$ \\
\hline$\Delta \mathrm{t}\left({ }^{\circ} \mathrm{C} \mathrm{m}^{-1}\right)$ & $0.17 \pm 0.43$ & $0.02 \pm 0.12$ & $0.02 \pm 0.08$ \\
\hline S & $36.78 \pm 1.38$ & $36.88 \pm 0.65$ & $37.87 \pm 0.49$ \\
\hline$\Delta \mathrm{S}\left(\mathrm{m}^{-1}\right)$ & $0.20 \pm 0.38$ & $0.04 \pm 0.05$ & $0.02 \pm 0.05$ \\
\hline$\sigma_{\mathrm{T}}\left(\mathrm{kg} \mathrm{m}^{-3}\right)$ & $27.62 \pm 0.82$ & $27.99 \pm 0.38$ & $28.36 \pm 0.35$ \\
\hline$\Delta \sigma_{\mathrm{T}}\left(\mathrm{kg} \mathrm{m}^{-4}\right)$ & $0.12 \pm 0.24$ & $0.03 \pm 0.03$ & $0.01 \pm 0.02$ \\
\hline $\mathrm{O}_{2}\left(\mathrm{mg} \mathrm{l}^{-1}\right)$ & $7.11 \pm 2.42$ & $6.80 \pm 2.32$ & $8.30 \pm 0.51$ \\
\hline $\mathrm{O}_{2}$ saturation $(\%)$ & $85.94 \pm 27.67$ & $81.89 \pm 27.01$ & $103.89 \pm 4.81$ \\
\hline $\left.\mathrm{AOU}(\mu \mathrm{mol} \mathrm{kg})^{-1}\right)$ & $34.01 \pm 68.01$ & $46.40 \pm 69.25$ & $-9.35 \pm 9.89$ \\
\hline OUR ( $\mu \mathrm{mol} \mathrm{kg} \mathrm{kg}^{-1}$ year $\left.^{-1}\right)$ & $153.04 \pm 306.05$ & $243.36 \pm 363.20$ & $\mathrm{n} / \mathrm{a}$ \\
\hline OCRR $\left(\mu \mathrm{mol} \mathrm{kg}{ }^{-1}\right.$ year $\left.^{-1}\right)$ & $105.60 \pm 211.18$ & $167.92 \pm 250.61$ & $\mathrm{n} / \mathrm{a}$ \\
\hline Chl $a\left(\mu \mathrm{g} \mathrm{l}^{-1}\right)$ & $0.40 \pm 0.28$ & $0.37 \pm 0.20$ & $0.29 \pm 0.18$ \\
\hline $\mathrm{NH}_{4}\left(\mu \mathrm{mol} \mathrm{l}{ }^{-1}\right)$ & $0.63 \pm 0.81$ & $0.23 \pm 0.09$ & $0.21 \pm 0.09$ \\
\hline $\mathrm{NO}_{2}\left(\mu \mathrm{mol} \mathrm{1^{-1 }}\right)$ & $0.27 \pm 0.58$ & $0.10 \pm 0.06$ & $0.11 \pm 0.08$ \\
\hline $\mathrm{NO}_{3}\left(\mu \mathrm{mol} \mathrm{l}^{-1}\right)$ & $0.98 \pm 0.92$ & $1.60 \pm 1.61$ & $0.83 \pm 0.73$ \\
\hline DIN $\left(\mu \mathrm{mol} \mathrm{1} 1^{-1}\right)$ & $1.88 \pm 1.70$ & $1.93 \pm 1.64$ & $1.15 \pm 0.68$ \\
\hline $\mathrm{PO}_{4}\left(\mu \mathrm{mol} \mathrm{l}^{-1}\right)$ & $0.09 \pm 0.12$ & $0.09 \pm 0.07$ & $0.08 \pm 0.07$ \\
\hline $\mathrm{P}_{\mathrm{oth}}\left(\mu \mathrm{mol} \mathrm{l}^{-1}\right)$ & $0.11 \pm 0.11$ & $0.11 \pm 0.16$ & $0.09 \pm 0.21$ \\
\hline $\mathrm{N}_{\mathrm{oth}}\left(\mu \mathrm{mol} \mathrm{1^{-1 }}\right)$ & $5.74 \pm 2.88$ & $7.46 \pm 4.94$ & $6.45 \pm 4.60$ \\
\hline DIN/PO & $27.57 \pm 20.48$ & $26.27 \pm 16.84$ & $17.35 \pm 10.84$ \\
\hline $\mathrm{SiO}_{4}\left(\mu \mathrm{mol} \mathrm{1} 1^{-1}\right)$ & $15.88 \pm 10.16$ & $17.02 \pm 13.76$ & $3.18 \pm 1.63$ \\
\hline $\mathrm{SiO}_{4} / \mathrm{DIN}$ & $12.77 \pm 9.24$ & $14.09 \pm 16.05$ & $4.16 \pm 3.25$ \\
\hline TRIX & $3.54 \pm 0.80$ & $3.57 \pm 0.67$ & $2.74 \pm 0.47$ \\
\hline $\mathrm{APF}\left(\mu \mathrm{g} \mathrm{C}^{-1}\right)$ & $2.90 \pm 4.90$ & $1.29 \pm 2.20$ & $2.12 \pm 3.65$ \\
\hline Cyano $\left(\mu g \mathrm{C}^{-1}\right)$ & $53.08 \pm 59.14$ & $98.13 \pm 88.22$ & $123.92 \pm 90.66$ \\
\hline $\mathrm{HBa}\left(\mu \mathrm{g} \mathrm{C} 1^{-1}\right)$ & $3.65 \pm 1.44$ & $3.81 \pm 2.65$ & $3.01 \pm 0.56$ \\
\hline $\mathrm{HPF}\left(\mu \mathrm{g} \mathrm{C}^{-1}\right)$ & $1.92 \pm 1.57$ & $1.22 \pm 0.82$ & $0.78 \pm 0.76$ \\
\hline
\end{tabular}

Table S4. - Mean \pm sd of the analysed parameters in the stratification period (April 2010-September 2010). See the list of abbreviations in Table S1.

\begin{tabular}{|c|c|c|c|}
\hline Parameter & Small Lake & Big Lake & Gonoturska \\
\hline 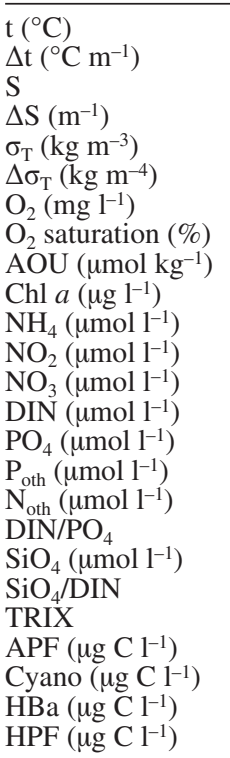 & $\begin{array}{c}17.96 \pm 4.68 \\
-0.38 \pm 0.57 \\
36.73 \pm 0.72 \\
0.05 \pm 0.13 \\
26.52 \pm 1.43 \\
0.14 \pm 0.16 \\
7.20 \pm 1.97 \\
96.72 \pm 28.38 \\
11.18 \pm 70.22 \\
0.62 \pm 0.33 \\
0.35 \pm 0.24 \\
0.12 \pm 0.20 \\
0.27 \pm 0.34 \\
0.75 \pm 0.65 \\
0.04 \pm 0.04 \\
0.08 \pm 0.06 \\
5.08 \pm 3.30 \\
29.34 \pm 33.73 \\
11.29 \pm 7.72 \\
22.81 \pm 18.31 \\
3.02 \pm 0.90 \\
3.06 \pm 4.55 \\
53.71 \pm 63.19 \\
4.59 \pm 2.72 \\
2.37 \pm 2.43\end{array}$ & $\begin{array}{c}15.89 \pm 5.02 \\
-0.25 \pm 0.40 \\
36.73 \pm 0.48 \\
0.00 \pm 0.05 \\
26.99 \pm 1.16 \\
0.07 \pm 0.08 \\
7.37 \pm 1.74 \\
94.59 \pm 26.38 \\
17.27 \pm 65.95 \\
0.40 \pm 0.26 \\
0.24 \pm 0.18 \\
0.06 \pm 0.05 \\
0.45 \pm 0.61 \\
0.75 \pm 0.68 \\
0.04 \pm 0.05 \\
0.12 \pm 0.17 \\
4.19 \pm 3.26 \\
30.51 \pm 39.67 \\
10.90 \pm 8.85 \\
19.14 \pm 14.52 \\
2.90 \pm 1.07 \\
1.53 \pm 1.60 \\
93.37 \pm 123.60 \\
3.82 \pm 1.43 \\
2.09 \pm 1.21\end{array}$ & $\begin{array}{c}16.94 \pm 2.27 \\
-0.12 \pm 0.15 \\
38.21 \pm 0.42 \\
0.02 \pm 0.03 \\
27.97 \pm 0.72 \\
0.04 \pm 0.05 \\
8.52 \pm 0.44 \\
112.02 \pm 4.96 \\
-27.65 \pm 10.95 \\
0.18 \pm 0.17 \\
0.20 \pm 0.12 \\
0.03 \pm 0.02 \\
0.13 \pm 0.11 \\
0.35 \pm 0.18 \\
0.03 \pm 0.04 \\
0.08 \pm 0.06 \\
3.57 \pm 1.96 \\
19.26 \pm 16.99 \\
2.65 \pm 1.19 \\
10.66 \pm 9.07 \\
1.71 \pm 0.56 \\
1.18 \pm 1.29 \\
43.75 \pm 51.53 \\
3.76 \pm 0.87 \\
1.17 \pm 0.73\end{array}$ \\
\hline
\end{tabular}

Table S5. - Significant $(\mathrm{p}<0.05)$ differences in the study locations between the periods of mixing (October 2009-March 2010) and stratification (April 2010-September 2010). See the list of abbreviations in Table S1.

\begin{tabular}{|c|c|c|c|}
\hline & Small Lake & Big Lake & Gonoturska Bay \\
\hline $\begin{array}{l}\text { differences } \\
\text { at } \mathrm{p}<0.05\end{array}$ & $\begin{array}{c}\mathrm{t}, \Delta \mathrm{t}, \sigma_{\mathrm{T}}, \Delta \mathrm{S}, \\
\mathrm{Chl} a, \\
\mathrm{NO}_{3}, \mathrm{NH}_{4}, \mathrm{PO}_{4}, \mathrm{SiO}_{4}, \\
\mathrm{SiO}_{4} / \mathrm{DIN}, \mathrm{TRIX}\end{array}$ & $\begin{array}{c}\mathrm{S}, \Delta \mathrm{S}, \mathrm{t}, \Delta \mathrm{t}, \sigma_{\mathrm{T}}, \Delta \sigma_{\mathrm{T}} \\
\mathrm{AOU}, \mathrm{O}_{2} \text { sat., } \\
\mathrm{NO}_{3}, \mathrm{NO}_{2}, \mathrm{PO}_{4}, \mathrm{SiO}_{4}, \mathrm{~N}_{\text {oth }}, \\
\mathrm{SiO}_{4} / \mathrm{DIN}, \mathrm{TRIX}, \mathrm{HPF}\end{array}$ & $\begin{array}{c}\mathrm{S}, \mathrm{t}, \Delta \mathrm{t}, \sigma_{\mathrm{T}}, \Delta \sigma_{\mathrm{T}}, \\
\mathrm{O}_{2}, \mathrm{AOU}, \mathrm{O}_{2} \text { sat., } \mathrm{Chl} a, \\
\mathrm{NO}_{3}, \mathrm{NO}_{2}, \mathrm{PO}_{4}, \mathrm{SiO}_{4}, \mathrm{~N}_{\text {oth }}, \mathrm{SiO}_{4} / \mathrm{DIN}, \mathrm{TRIX}, \\
\text { Cyano, } \mathrm{HBa}\end{array}$ \\
\hline
\end{tabular}


Table S6. - Mean \pm sd of the analysed parameters in the upper waters of the study locations within the stratification period (April 2010-September 2010); n/a, not analysed; OUR, oxygen utilization rate; OCRR, organic carbon remineralization rate. See the list of abbreviations in Table S1.

\begin{tabular}{|c|c|c|c|}
\hline Parameter & Small Lake $\leq 10 \mathrm{~m}$ & Big Lake $\leq 17 \mathrm{~m}$ & Gonoturska $\leq 20 \mathrm{~m}$ \\
\hline $\mathrm{t}\left({ }^{\circ} \mathrm{C}\right)$ & $22.78 \pm 3.88$ & $21.14 \pm 3.83$ & $18.73 \pm 2.39$ \\
\hline$\Delta \mathrm{t}\left({ }^{\circ} \mathrm{C} \mathrm{m}^{-1}\right)$ & $-0.45 \pm 0.61$ & $-0.31 \pm 0.35$ & $-0.18 \pm 0.19$ \\
\hline $\mathrm{S}$ & $36.33 \pm 0.99$ & $36.72 \pm 0.72$ & $37.94 \pm 0.51$ \\
\hline$\Delta \mathrm{S}\left(\mathrm{m}^{-1}\right)$ & $0.08 \pm 0.19$ & $0.00 \pm 0.05$ & $0.03 \pm 0.04$ \\
\hline$\sigma_{\mathrm{T}}\left(\mathrm{kg} \mathrm{m}^{-3}\right)$ & $24.94 \pm 0.94$ & $25.70 \pm 0.73$ & $27.31 \pm 0.67$ \\
\hline$\Delta \sigma_{\mathrm{T}}\left(\mathrm{kg} \mathrm{m}^{-4}\right)$ & $0.19 \pm 0.23$ & $0.08 \pm 0.08$ & $0.07 \pm 0.06$ \\
\hline $\mathrm{O}_{2}\left(\mathrm{mg} \mathrm{l}^{-1}\right)$ & $8.25 \pm 0.73$ & $8.33 \pm 0.72$ & $8.49 \pm 0.51$ \\
\hline $\mathrm{O}_{2}$ saturation $(\%)$ & $117.22 \pm 8.36$ & $116.55 \pm 6.57$ & $114.03 \pm 4.74$ \\
\hline $\mathrm{AOU}\left(\mu \mathrm{mol} \mathrm{kg} \mathrm{kg}^{-1}\right)$ & $-36.66 \pm 17.32$ & $-35.97 \pm 13.89$ & $-31.76 \pm 10.52$ \\
\hline OUR $\left(\mu \mathrm{mol} \mathrm{kg}{ }^{-1}\right.$ year-1 $\left.^{-1}\right)$ & $-307.29 \pm 145.17$ & $-364.29 \pm 140.75$ & $\mathrm{n} / \mathrm{a}$ \\
\hline OCRR $\left(\mu \mathrm{mol} \mathrm{kg}{ }^{-1}\right.$ year $\left.^{-1}\right)$ & $-212.03 \pm 100.17$ & $-251.36 \pm 97.12$ & $\mathrm{n} / \mathrm{a}$ \\
\hline Chl $a\left(\mu \mathrm{g} \mathrm{l}^{-1}\right)$ & $0.53 \pm 0.37$ & $0.19 \pm 0.14$ & $0.04 \pm 0.06$ \\
\hline $\mathrm{NH}_{4}\left(\mu \mathrm{mol} \mathrm{l^{-1 }}\right)$ & $0.29 \pm 0.17$ & $0.21 \pm 0.10$ & $0.22 \pm 0.15$ \\
\hline $\mathrm{NO}_{2}\left(\mu \mathrm{mol} \mathrm{l} l^{-1}\right)$ & $0.03 \pm 0.02$ & $0.02 \pm 0.010$ & $0.02 \pm 0.01$ \\
\hline $\mathrm{NO}_{3}\left(\mu \mathrm{mol} \mathrm{1} 1^{-1}\right)$ & $0.13 \pm 0.14$ & $0.09 \pm 0.07$ & $0.14 \pm 0.12$ \\
\hline $\operatorname{DIN}\left(\mu \mathrm{mol} \mathrm{l}^{-1}\right)$ & $0.46 \pm 0.29$ & $0.33 \pm 0.13$ & $0.38 \pm 0.19$ \\
\hline $\mathrm{PO}_{4}\left(\mu \mathrm{mol} \mathrm{1} 1^{-1}\right)$ & $0.04 \pm 0.05$ & $0.03 \pm 0.01$ & $0.03 \pm 0.04$ \\
\hline $\mathrm{P}_{\mathrm{oth}}\left(\mu \mathrm{mol} \mathrm{l} \mathrm{l}^{-1}\right)$ & $0.08 \pm 0.07$ & $0.12 \pm 0.24$ & $0.07 \pm 0.03$ \\
\hline $\mathrm{N}_{\mathrm{oth}}\left(\mu \mathrm{mol} \mathrm{l^{-1 }}\right)$ & $5.03 \pm 2.14$ & $4.13 \pm 3.67$ & $3.68 \pm 1.90$ \\
\hline $\mathrm{DIN} / \mathrm{PO}_{4}$ & $17.68 \pm 18.18$ & $16.06 \pm 13.31$ & $18.40 \pm 16.11$ \\
\hline $\mathrm{SiO}_{4}\left(\mu \mathrm{mol} \mathrm{l} 1^{-1}\right)$ & $6.89 \pm 3.29$ & $3.70 \pm 1.41$ & $2.67 \pm 1.06$ \\
\hline $\mathrm{SiO}_{4} / \mathrm{DIN}$ & $20.99 \pm 16.56$ & $13.28 \pm 7.31$ & $10.66 \pm 10.06$ \\
\hline TRIX & $2.40 \pm 0.56$ & $2.00 \pm 0.61$ & $1.40 \pm 0.53$ \\
\hline $\mathrm{APF}\left(\mu \mathrm{g} \mathrm{Cl}^{-1}\right)$ & $4.11 \pm 5.52$ & $1.12 \pm 0.87$ & $0.96 \pm 0.95$ \\
\hline Cyano $\left(\mu \mathrm{g} \mathrm{C}^{-1}\right)$ & $75.00 \pm 74.79$ & $117.20 \pm 133.10$ & $44.21 \pm 56.16$ \\
\hline $\mathrm{HBa}\left(\mu \mathrm{g} \mathrm{C} 1^{-1}\right)$ & $4.66 \pm 2.92$ & $3.73 \pm 1.17$ & $3.77 \pm 0.90$ \\
\hline $\mathrm{HPF}\left(\mu \mathrm{g} \mathrm{Cl}^{-1}\right)$ & $2.42 \pm 2.98$ & $1.95 \pm 1.07$ & $1.11 \pm 0.72$ \\
\hline
\end{tabular}

Table S7. - Mean \pm sd of the analysed parameters in the deep waters of the study locations within the stratification period (April 2010-September 2010). See the list of abbreviations in Table S1.

\begin{tabular}{|c|c|c|c|}
\hline Parameter & Small Lake $\geq 15 \mathrm{~m}$ & Big Lake $\geq 21 \mathrm{~m}$ & Gonoturska $\geq 21 \mathrm{~m}$ \\
\hline $\mathrm{t}\left({ }^{\circ} \mathrm{C}\right)$ & $14.39 \pm 0.79$ & $12.27 \pm 1.36$ & $15.74 \pm 1.12$ \\
\hline$\Delta \mathrm{t}\left({ }^{\circ} \mathrm{C} \mathrm{m} \mathrm{m}^{-1}\right)$ & $-0.16 \pm 0.32$ & $-0.15 \pm 0.35$ & $-0.08 \pm 0.09$ \\
\hline $\mathrm{S}$ & $37.06 \pm 0.27$ & $36.74 \pm 0.15$ & $38.39 \pm 0.19$ \\
\hline$\Delta \mathrm{S}\left(\mathrm{m}^{-1}\right)$ & $0.06 \pm 0.06$ & $0.01 \pm 0.05$ & $0.01 \pm 0.01$ \\
\hline$\sigma_{\mathrm{T}}\left(\mathrm{kg} \mathrm{m}^{-3}\right)$ & $27.69 \pm 0.34$ & $27.88 \pm 0.29$ & $28.41 \pm 0.30$ \\
\hline$\Delta \sigma_{\mathrm{T}}\left(\mathrm{kg} \mathrm{m}^{-4}\right)$ & $0.08 \pm 0.06$ & $0.04 \pm 0.06$ & $0.03 \pm 0.03$ \\
\hline $\mathrm{O}_{2}\left(\mathrm{mg} \mathrm{l}^{-1}\right)$ & $6.16 \pm 2.27$ & $6.27 \pm 1.76$ & $8.58 \pm 0.27$ \\
\hline $\mathrm{O}_{2}$ saturation $(\%)$ & $76.22 \pm 28.58$ & $73.42 \pm 21.06$ & $108.78 \pm 3.42$ \\
\hline $\mathrm{AOU}\left(\mu \mathrm{mol} \mathrm{kg}{ }^{-1}\right)$ & $59.03 \pm 70.73$ & $69.45 \pm 54.87$ & $-21.02 \pm 8.18$ \\
\hline Chl $a\left(\mu \mathrm{g} \mathrm{l}^{-1}\right)$ & $0.66 \pm 0.29$ & $0.55 \pm 0.22$ & $0.26 \pm 0.16$ \\
\hline $\mathrm{NH}_{4}\left(\mu \mathrm{mol} \mathrm{1^{-1 }}\right)$ & $0.42 \pm 0.29$ & $0.26 \pm 0.24$ & $0.16 \pm 0.06$ \\
\hline $\mathrm{NO}_{2}\left(\mu \mathrm{mol} \mathrm{l^{-1 }}\right)$ & $0.20 \pm 0.26$ & $0.09 \pm 0.06$ & $0.03 \pm 0.03$ \\
\hline $\mathrm{NO}_{3}\left(\mu \mathrm{mol} \mathrm{l}^{-1}\right)$ & $0.41 \pm 0.41$ & $0.83 \pm 0.68$ & $0.12 \pm 0.09$ \\
\hline $\operatorname{DIN}\left(\mu \mathrm{mol} 1^{-1}\right)$ & $1.03 \pm 0.78$ & $1.18 \pm 0.75$ & $0.31 \pm 0.15$ \\
\hline $\mathrm{PO}_{4}\left(\mu \mathrm{mol} \mathrm{l^{-1 }}\right)$ & $0.04 \pm 0.04$ & $0.05 \pm 0.06$ & $0.03 \pm 0.04$ \\
\hline $\mathrm{P}_{\mathrm{oth}}\left(\mu \mathrm{mol} \mathrm{l}^{-1}\right)$ & $0.08 \pm 0.03$ & $0.14 \pm 0.11$ & $0.10 \pm 0.10$ \\
\hline $\mathrm{N}_{\mathrm{oth}}\left(\mu \mathrm{mol} \mathrm{1^{-1 }}\right)$ & $5.01 \pm 4.13$ & $4.48 \pm 3.15$ & $3.39 \pm 2.08$ \\
\hline $\mathrm{DIN} / \mathrm{PO}_{4}$ & $42.67 \pm 40.82$ & $44.21 \pm 51.00$ & $20.51 \pm 18.63$ \\
\hline $\mathrm{SiO}_{4}\left(\mu \mathrm{mol} \mathrm{l} l^{-1}\right)$ & $15.36 \pm 8.51$ & $17.39 \pm 8.22$ & $2.63 \pm 1.32$ \\
\hline $\mathrm{SiO}_{4} / \mathrm{DIN}$ & $24.32 \pm 19.81$ & $22.56 \pm 17.56$ & $10.67 \pm 7.49$ \\
\hline TRIX & $3.65 \pm 0.71$ & $3.72 \pm 0.74$ & $2.00 \pm 0.42$ \\
\hline $\operatorname{APF}\left(\mu \mathrm{g} \mathrm{C}^{-1}\right)$ & $1.57 \pm 2.08$ & $1.99 \pm 2.27$ & $2.16 \pm 2.25$ \\
\hline Cyano $\left(\mu \mathrm{g} \mathrm{C}^{-1}\right)$ & $60.64 \pm 72.65$ & $83.43 \pm 128.79$ & $41.67 \pm 26.69$ \\
\hline $\mathrm{HBa}\left(\mu \mathrm{g} \mathrm{C} 1^{-1}\right)$ & $4.49 \pm 2.54$ & $3.48 \pm 1.05$ & $3.73 \pm 0.85$ \\
\hline $\mathrm{HPF}\left(\mu \mathrm{g} \mathrm{C}^{-1}\right)$ & $2.31 \pm 1.45$ & $2.32 \pm 1.54$ & $1.44 \pm 0.85$ \\
\hline
\end{tabular}

Table S8. - Significant $(\mathrm{p}<0.05)$ differences at the study locations above and below the thermocline during the stratification period (April 2010-September 2010). See the list of abbreviations in Table S1.

\begin{tabular}{|c|c|c|c|}
\hline & Small Lake & Big Lake & Gonoturska Bay \\
\hline $\begin{array}{l}\text { Parameters with } \\
\text { differences } \\
\text { at } p<0.05\end{array}$ & $\begin{array}{c}\text { t, } \Delta \mathrm{t}, \mathrm{S}, \sigma_{\mathrm{T}}, \Delta \sigma_{\mathrm{T}}, \\
\mathrm{O}_{2}, \mathrm{AOU}, \mathrm{O}_{2} \text { sat., Chl } a, \mathrm{NO}_{3}, \mathrm{NO}_{2}, \mathrm{SiO}_{4}, \\
\text { DIN/PO } \\
\text {, TRIX, Cyano, APF }\end{array}$ & $\begin{array}{c}\mathrm{t}, \Delta \mathrm{t}, \sigma_{\mathrm{T}}, \Delta \sigma_{\mathrm{T}}, \\
\mathrm{O}_{2}, \mathrm{AOU} \mathrm{O}_{2} \text { sat.., } \\
\mathrm{Chl} a, \mathrm{NO}_{3}, \mathrm{NO}_{2}, \mathrm{PO}_{4}, \\
\mathrm{DIN} / \mathrm{PO}_{4}, \mathrm{SiO}_{4}, \mathrm{SiO}_{4} / \mathrm{DIN}, \\
\text { TRIX }\end{array}$ & 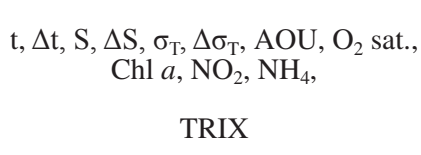 \\
\hline
\end{tabular}


Table S9. - Mean \pm sd of the analysed parameters in the upper waters of the study locations within the mixing period (October 2009-March 2010); n/a, not analysed; OUR, oxygen utilization rate; OCRR, organic carbon remineralization rate. See the list of abbreviations in Table S1.

\begin{tabular}{|c|c|c|c|}
\hline Parameter/Location & Small Lake $\leq 10 \mathrm{~m}$ & Big Lake $\leq 17 \mathrm{~m}$ & Gonoturska $\leq 20 \mathrm{~m}$ \\
\hline $\mathrm{t}\left({ }^{\circ} \mathrm{C}\right)$ & $12.75 \pm 2.33$ & $12.13 \pm 2.06$ & $14.13 \pm 1.74$ \\
\hline$\Delta \mathrm{t}\left({ }^{\circ} \mathrm{C} \mathrm{m}^{-1}\right)$ & $0.42 \pm 0.65$ & $0.05 \pm 0.11$ & $0.02 \pm 0.06$ \\
\hline $\mathrm{S}$ & $35.70 \pm 1.70$ & $36.45 \pm 0.71$ & $37.65 \pm 0.54$ \\
\hline$\Delta \mathrm{S}\left(\mathrm{m}^{-1}\right)$ & $0.46 \pm 0.55$ & $0.06 \pm 0.07$ & $0.02 \pm 0.04$ \\
\hline$\sigma_{\mathrm{T}}\left(\mathrm{kg} \mathrm{m}^{-3}\right)$ & $26.95 \pm 0.99$ & $27.67 \pm 0.33$ & $28.20 \pm 0.37$ \\
\hline$\Delta \sigma_{\mathrm{T}}\left(\mathrm{kg} \mathrm{m}^{-4}\right)$ & $0.29 \pm 0.35$ & $0.04 \pm 0.05$ & $0.01 \pm 0.02$ \\
\hline $\mathrm{O}_{2}\left(\mathrm{mg} \mathrm{l}^{-1}\right)$ & $8.67 \pm 0.97$ & $8.57 \pm 0.81$ & $8.32 \pm 0.44$ \\
\hline $\mathrm{O}_{2}$ saturation $(\%)$ & $103.62 \pm 7.69$ & $102.35 \pm 6.13$ & $103.88 \pm 3.74$ \\
\hline $\mathrm{AOU}\left(\mu \mathrm{mol} \mathrm{kg}{ }^{-1}\right)$ & $-9.66 \pm 20.32$ & $-6.28 \pm 16.14$ & $-9.39 \pm 8.64$ \\
\hline OUR ( umol kg $^{-1}$ year $\left.^{-1}\right)$ & $-43.47 \pm 91.43$ & $-32.92 \pm 84.68$ & $\mathrm{n} / \mathrm{a}$ \\
\hline OCRR $\left(\mu \mathrm{mol} \mathrm{kg}{ }^{-1}\right.$ year $\left.^{-1}\right)$ & $-30.00 \pm 63.09$ & $-22.72 \pm 58.43$ & $\mathrm{n} / \mathrm{a}$ \\
\hline Chl $a\left(\mu \mathrm{g}^{-1}\right)$ & $0.30 \pm 0.15$ & $0.34 \pm 0.17$ & $0.27 \pm 0.18$ \\
\hline $\mathrm{NH}_{4}\left(\right.$ umol l $\left.^{-1}\right)$ & $0.36 \pm 0.14$ & $0.24 \pm 0.07$ & $0.21 \pm 0.09$ \\
\hline $\mathrm{NO}_{2}\left(\mu \mathrm{mol} \mathrm{l} 1^{-1}\right)$ & $0.06 \pm 0.03$ & $0.08 \pm 0.04$ & $0.11 \pm 0.08$ \\
\hline $\mathrm{NO}_{3}\left(\mu \mathrm{mol} \mathrm{1} 1^{-1}\right)$ & $0.66 \pm 0.60$ & $1.02 \pm 0.90$ & $0.87 \pm 0.72$ \\
\hline DIN $\left(u m o l ~ 1^{-1}\right)$ & $1.08 \pm 0.66$ & $1.34 \pm 0.95$ & $1.19 \pm 0.68$ \\
\hline $\mathrm{PO}_{4}\left(\mu \mathrm{mol} \mathrm{l} \mathrm{l}^{-1}\right)$ & $0.10 \pm 0.15$ & $0.08 \pm 0.09$ & $0.09 \pm 0.08$ \\
\hline $\mathrm{P}_{\mathrm{oth}}\left(\mu \mathrm{mol} \mathrm{1^{-1 }}\right)$ & $0.11 \pm 0.10$ & $0.15 \pm 0.25$ & $0.05 \pm 0.04$ \\
\hline $\mathrm{N}_{\mathrm{oth}}\left(\mu \mathrm{mol} \mathrm{1^{-1 }}\right)$ & $5.84 \pm 2.74$ & $8.72 \pm 6.35$ & $6.04 \pm 3.96$ \\
\hline DIN/PO & $18.10 \pm 11.05$ & $22.57 \pm 15.48$ & $18.03 \pm 11.94$ \\
\hline $\mathrm{SiO}_{4}\left(\mu \mathrm{mol} \mathrm{l} 1^{-1}\right)$ & $11.94 \pm 5.54$ & $8.27 \pm 4.02$ & $3.65 \pm 1.83$ \\
\hline $\mathrm{SiO}_{4} / \mathrm{DIN}$ & $15.52 \pm 10.42$ & $10.64 \pm 8.95$ & $4.75 \pm 3.66$ \\
\hline TRIX & $3.02 \pm 0.68$ & $3.10 \pm 0.58$ & $2.70 \pm 0.48$ \\
\hline $\mathrm{APF}\left(\mu \mathrm{g} \mathrm{C} 1^{-1}\right)$ & $2.53 \pm 5.15$ & $1.57 \pm 2.84$ & $2.12 \pm 3.81$ \\
\hline Cyano $\left(\mu g \mathrm{C}^{-1}\right)$ & $47.96 \pm 40.27$ & $108.63 \pm 94.97$ & $139.18 \pm 91.65$ \\
\hline $\mathrm{HBa}\left(\mu \mathrm{g} \mathrm{C} 1^{-1}\right)$ & $3.76 \pm 1.30$ & $4.14 \pm 3.31$ & $3.03 \pm 0.50$ \\
\hline $\mathrm{HPF}\left(\mu \mathrm{g} \mathrm{C} 1^{-1}\right)$ & $1.77 \pm 1.12$ & $1.18 \pm 0.89$ & $0.79 \pm 0.78$ \\
\hline
\end{tabular}

Table S10. - Mean \pm sd of the analysed parameters in the deep waters of the study locations within the mixing period (October 2009-March 2010); n/a, not analysed; OUR, oxygen utilization rate; OCRR, organic carbon remineralization rate. See the list of abbreviations in Table S1.

\begin{tabular}{|c|c|c|c|}
\hline Parameter/Location & Small Lake $\geq 15 \mathrm{~m}$ & Big Lake $\geq 21 \mathrm{~m}$ & Gonoturska $\geq 21 \mathrm{~m}$ \\
\hline $\mathrm{t}\left({ }^{\circ} \mathrm{C}\right)$ & $14.26 \pm 1.25$ & $12.26 \pm 1.12$ & $14.27 \pm 1.00$ \\
\hline$\Delta \mathrm{t}\left({ }^{\circ} \mathrm{C} \mathrm{m}^{-1}\right)$ & $0.06 \pm 0.12$ & $-0.00 \pm 0.10$ & $0.02 \pm 0.09$ \\
\hline $\mathrm{S}$ & $37.56 \pm 0.42$ & $37.18 \pm 0.40$ & $38.04 \pm 0.37$ \\
\hline$\Delta \mathrm{S}\left(\mathrm{m}^{-1}\right)$ & $0.07 \pm 0.06$ & $0.03 \pm 0.03$ & $0.02 \pm 0.05$ \\
\hline$\sigma_{\mathrm{T}}\left(\mathrm{kg} \mathrm{m}^{-3}\right)$ & $28.11 \pm 0.20$ & $28.23 \pm 0.23$ & $28.48 \pm 0.29$ \\
\hline$\Delta \sigma_{\mathrm{T}}\left(\mathrm{kg} \mathrm{m}^{-4}\right)$ & $0.04 \pm 0.04$ & $0.02 \pm 0.02$ & $0.01 \pm 0.02$ \\
\hline $\mathrm{O}_{2}\left(\mathrm{mg} \mathrm{l}^{-1}\right)$ & $5.57 \pm 2.46$ & $5.15 \pm 2.17$ & $8.26 \pm 0.41$ \\
\hline $\mathrm{O}_{2}$ saturation $(\%)$ & $68.26 \pm 29.28$ & $62.61 \pm 26.03$ & $103.92 \pm 5.06$ \\
\hline $\mathrm{AOU}\left(\mu \mathrm{mol} \mathrm{kg}{ }^{-1}\right)$ & $77.68 \pm 71.29$ & $95.98 \pm 66.42$ & $-9.28 \pm 12.09$ \\
\hline OUR ( $\mu \mathrm{mol} \mathrm{kg} \mathrm{kg}^{-1}$ year $\left.^{-1}\right)$ & $349.56 \pm 320.80$ & $503.40 \pm 348.37$ & $\mathrm{n} / \mathrm{a}$ \\
\hline OCRR $\left(\mu \mathrm{mol} \mathrm{kg} \mathrm{kg}^{-1}\right.$ year $\left.^{-1}\right)$ & $241.20 \pm 221.35$ & $347.35 \pm 240.37$ & $\mathrm{n} / \mathrm{a}$ \\
\hline Chl $a\left(\mu \mathrm{g} \mathrm{l}^{-1}\right)$ & $0.46 \pm 0.35$ & $0.38 \pm 0.22$ & $0.30 \pm 0.17$ \\
\hline $\mathrm{NH}_{4}\left(\mu \mathrm{mol} \mathrm{1} 1^{-1}\right)$ & $0.90 \pm 1.08$ & $0.23 \pm 0.10$ & $0.22 \pm 0.10$ \\
\hline $\mathrm{NO}_{2}\left(\mu \mathrm{mol} \mathrm{1^{-1 }}\right)$ & $0.48 \pm 0.78$ & $0.11 \pm 0.06$ & $0.12 \pm 0.09$ \\
\hline $\mathrm{NO}_{3}\left(\mu \mathrm{mol} \mathrm{1} 1^{-1}\right)$ & $1.30 \pm 1.08$ & $2.20 \pm 1.92$ & $0.76 \pm 0.76$ \\
\hline DIN $\left(\mu \mathrm{mol} \mathrm{1} 1^{-1}\right)$ & $2.68 \pm 2.04$ & $2.54 \pm 1.94$ & $1.10 \pm 0.68$ \\
\hline $\mathrm{PO}_{4}\left(\mu \mathrm{mol} \mathrm{1} 1^{-1}\right)$ & $0.09 \pm 0.06$ & $0.09 \pm 0.05$ & $0.08 \pm 0.05$ \\
\hline $\mathrm{P}_{\mathrm{oth}}\left(\mu \mathrm{mol} \mathrm{1^{-1 }}\right)$ & $0.11 \pm 0.13$ & $0.09 \pm 0.03$ & $0.16 \pm 0.34$ \\
\hline $\mathrm{N}_{\mathrm{oth}}\left(\mu \mathrm{mol} \mathrm{1^{-1 }}\right)$ & $5.64 \pm 3.08$ & $6.64 \pm 3.81$ & $7.16 \pm 5.62$ \\
\hline DIN/PO 4 & $37.04 \pm 23.49$ & $29.25 \pm 16.99$ & $16.15 \pm 8.78$ \\
\hline $\mathrm{SiO}_{4}\left(\mu \mathrm{mol} 1^{-1}\right)$ & $19.83 \pm 12.20$ & $25.94 \pm 14.33$ & $2.35 \pm 0.64$ \\
\hline $\mathrm{SiO}_{4} / \mathrm{DIN}$ & $10.01 \pm 7.14$ & $17.58 \pm 20.62$ & $3.11 \pm 2.09$ \\
\hline TRIX & $4.06 \pm 0.53$ & $4.01 \pm 0.50$ & $2.81 \pm 0.47$ \\
\hline $\mathrm{APF}\left(\mu \mathrm{g} \mathrm{C} 1^{-1}\right)$ & $3.49 \pm 4.65$ & $0.87 \pm 0.63$ & $2.13 \pm 3.53$ \\
\hline Cyano ( $\left.\mu g \mathrm{C}^{-1}\right)$ & $61.46 \pm 83.13$ & $67.23 \pm 71.17$ & $66.67 \pm 67.68$ \\
\hline $\mathrm{HBa}\left(\mu \mathrm{g} \mathrm{C} 1^{-1}\right)$ & $3.46 \pm 1.70$ & $3.36 \pm 1.39$ & $2.92 \pm 0.86$ \\
\hline $\mathrm{HPF}\left(\mu \mathrm{g} \mathrm{C}^{-1}\right)$ & $2.17 \pm 2.17$ & $1.37 \pm 0.87$ & $0.73 \pm 0.76$ \\
\hline
\end{tabular}

Table S11. - Significant $(\mathrm{p}<0.05)$ differences between upper and deep waters at the study locations during the mixing period $($ October 2009-March 2010). OUR, oxygen utilization rate; OCRR, organic carbon remineralization rate; OUR and OCRR were not estimated for Gonoturska Bay. See the list of abbreviations in Table S1.

\begin{tabular}{|c|c|c|c|}
\hline & Small Lake & Big Lake & Gonoturska \\
\hline $\begin{array}{l}\text { Parameters with } \\
\text { differences } \\
\text { at } \mathrm{p}<0.05\end{array}$ & $\begin{array}{c}\mathrm{t}, \Delta \mathrm{t}, \mathrm{S}, \Delta \mathrm{S}, \sigma_{\mathrm{T}}, \Delta \sigma_{\mathrm{T}}, \mathrm{O}_{2}, \mathrm{O}_{2} \text { sat., } \mathrm{AOU} \\
\mathrm{OUR}, \mathrm{OCRR}, \mathrm{Chl} a, \text { TRIX, } \\
\mathrm{SiO}_{4}, \mathrm{NO}_{3}, \mathrm{NO}_{2}, \mathrm{NH}_{4}, \mathrm{DIN}_{\mathrm{PO}}\end{array}$ & $\begin{array}{c}\Delta \mathrm{t}, \mathrm{S}, \Delta \mathrm{S}, \sigma_{\mathrm{T}}, \\
\Delta \sigma_{\mathrm{T}}, \mathrm{O}_{2}, \mathrm{O}_{2} \text { sat., AOU, OUR, OCRR, TRIX, } \\
\mathrm{SiO}_{4}, \mathrm{NO}_{3}, \mathrm{NO}_{2}\end{array}$ & $\begin{array}{l}\mathrm{S}, \sigma_{\mathrm{T}} \\
\mathrm{SiO}_{4}\end{array}$ \\
\hline
\end{tabular}


Table S12. - Significant $(\mathrm{p}<0.05)$ differences within the specified water layers between the periods of mixing and stratification at the study locations. OUR, oxygen utilization rate; OCRR, organic carbon remineralization rate; OUR and OCRR were not estimated for Gonoturska Bay. See the list of abbreviations in Table S1.

\begin{tabular}{|c|c|c|c|c|}
\hline & Layer & Small Lake & Big Lake & Gonoturska \\
\hline 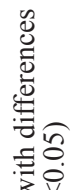 & $\begin{array}{l}\text { Upper } \\
\text { water }\end{array}$ & $\begin{array}{c}\text { t, } \Delta \mathrm{t}, \mathrm{S}, \Delta \mathrm{S}, \sigma_{\mathrm{T}}, \\
\mathrm{O}_{2} \text { sat., } \mathrm{AOU}, \mathrm{OUR}, \mathrm{OCRR}, \\
\mathrm{Chl} a, \mathrm{TRIX}, \\
\mathrm{NO}_{3}, \mathrm{NO}_{2}, \mathrm{SiO}_{4}\end{array}$ & $\begin{array}{c}\mathrm{t}, \Delta \mathrm{t}, \mathrm{S}, \Delta \mathrm{S}, \sigma_{\mathrm{T}}, \Delta \sigma_{\mathrm{T}}, \\
\mathrm{O}_{2} \text { sat., } \mathrm{AOU}, \mathrm{OUR}, \mathrm{OCRR}, \\
\mathrm{Chl} a, \mathrm{TRIX} \\
\mathrm{NO}_{3}, \mathrm{NO}_{2}, \mathrm{PO}_{4}, \mathrm{SiO}_{4}, \\
\mathrm{~N}_{\mathrm{oth}}, \mathrm{HPF}\end{array}$ & $\begin{array}{c}\text { t, } \Delta \mathrm{t}, \mathrm{S}, \Delta \mathrm{S}, \sigma_{\mathrm{T}}, \Delta \sigma_{\mathrm{T}}, \\
\mathrm{O}_{2} \text { sat., AOU, } \\
\mathrm{Chl} a, \mathrm{TRIX} \\
\mathrm{NO}_{2}, \mathrm{NO}_{3}, \mathrm{SiO}_{4}, \mathrm{PO}_{4}, \\
\mathrm{SiO}_{4} / \mathrm{DIN}, \\
\mathrm{N}_{\text {oth }}, \mathrm{Cyano}, \mathrm{HBa}\end{array}$ \\
\hline 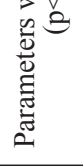 & $\begin{array}{l}\text { Deep } \\
\text { water }\end{array}$ & $\begin{array}{c}\mathrm{S}, \Delta \mathrm{t}, \sigma_{\mathrm{T}}, \Delta \sigma_{\mathrm{T}}, \\
\mathrm{Chl} a, \\
\mathrm{NO}_{3}, \mathrm{PO}_{4}, \mathrm{SiO}_{4} / \mathrm{DIN}\end{array}$ & $\begin{array}{c}\Delta \mathrm{t}, \mathrm{S}, \Delta \mathrm{S}, \sigma_{\mathrm{T}}, \Delta \sigma_{\mathrm{T}} \\
\mathrm{O}_{2} \\
\mathrm{Chl}^{2} a \\
\mathrm{NO}_{3}, \mathrm{PO}_{4}, \mathrm{SiO}_{4}, \\
\mathrm{~N}_{\mathrm{oth}}, \mathrm{P}_{\mathrm{oth}}\end{array}$ & $\begin{array}{c}\text { t, } \Delta \mathrm{t}, \mathrm{S}, \\
\mathrm{O}_{2}, \mathrm{O}_{2} \text { sat., } \mathrm{AOU}, \\
\mathrm{NO}_{2}, \mathrm{NO}_{3}, \mathrm{NH}_{4}, \mathrm{PO}_{4}, \\
\mathrm{~N}_{\text {oth, }} \\
\mathrm{SiO}_{4} / \mathrm{DIN}, \mathrm{TRIX}\end{array}$ \\
\hline
\end{tabular}

